\title{
Sustainable community development: integrating environmental, economic, and social objectives ${ }^{2 / 2}$
}

\author{
Mark Roseland \\ Community Economic Development Centre, Department of Geography, Simon Fraser University, \\ Burnaby, British Columbia, Canada V5A 1 S6
}

\begin{abstract}
The purpose of this article is to stimulate and inform discussion about the community role in sustainable development and to broaden our understanding of the opportunities for sustainable community development activity. It begins with an overview of sustainable development, questioning its focus on poverty as a major source of environmental degradation, and suggesting instead that both poverty and environmental degradation result largely from wealth. It next examines the concepts of natural capital and social capital, whether (and if so, how) they are linked, and explores their implications for sustainable development at the community level.

Chapter 3 examines planning theory and sustainable development, finds that while planning theory is, or should be, relevant to sustainable development, planners concerned with key aspects of sustainable development will have to look to "greener" pastures for relevant theoretical guidance.

Chapter 4 considers the implications for achieving sustainable development in communities, particularly regarding the future of work and community economic development. Chapter 5 details a framework for sustainable community development. Chapter 6 concerns questions of governance for sustainable community development and it focuses on public participation, decision-making, the role of local government, and planning for action. Chapter 7 examines relevant policy instruments and planning tools. Finally, Chapter 8 explores the challenge ahead for sustainable community development. (C) 2000 Elsevier Science Ltd All rights reserved.
\end{abstract}

\footnotetext{
This article is adapted in large part from my book Toward Sustainable Communities: Resources for Citizens and Their Governments. New Society Publishers, Gabriola Island, BC, 1998. An earlier version of the chapter on natural capital and social capital appeared in Pierce, J.T. and Dale, A. (ed.), Communities, Development, and Sustainability across Canada, UBC Press, Vancouver, 1999, pp. 190-207, and an expanded version of the chapter on policy instruments first appeared in 1996 in: Local Environment 1(2).
} 


\section{CHAPTER 1}

\section{Introduction}

In the context of growing concern over the global environment and related quality of life issues (e.g. WCED, 1987; UNCED, 1992; ICPQL, 1996), the purpose of this article is to stimulate and inform discussion about the community role in sustainable development and to broaden our understanding of the opportunities for sustainable community development activity.

While there has been considerable attention in recent years to thinking globally (e.g. the Montreal Accord on stratospheric ozone protection; the Rio "Earth Summit;" the Kyoto Summit), relatively little attention has been devoted to examining local activity within this global context. Our communities as presently planned and developed are not sustainable in a global ecological sense. A typical North American city of 100000 inhabitants imports 200 tons of food, 1000 tons of fuel, and 62000 tons of water every day; it exports 100000 tons of garbage and 40000 tons of human waste each year (Morris, 1990a,b). Indeed, it is these unsustainably "developed" cities of the world that produce most of the world's solid and liquid wastes, consume most of the world's fossil fuels, emit the majority of ozone depleting compounds and toxic gases, and give economic incentive to the clearing of the world's forests and agricultural lands (UNEP, 1990).

Seemingly ordinary local planning and development decisions have a significant impact on global environmental sustainability (see e.g. City of Vancouver, 1990; Haughton and Hunter, 1994; Wackernagel and Rees, 1996). Although local governments are not necessarily the only agencies charged with community planning and development, they are the only locally elected, representative and accountable bodies responsible for community decision-making. This makes them critical players in the movement toward sustainable communities (Roseland, 1997, 1998). Indeed, "it is clear that if the agreements reached at the Earth Summit in Rio in 1992 are to be implemented, most, if not all will require concerted action at the local level" (Agyeman and Evans, 1996).

This article complements recent publications in Progress in Planning concerned with sustainability (e.g. Mazza and Ryden, 1997; Feitelson, 1998), although it takes a different approach. It begins with an overview of sustainable development, questioning its focus on poverty as a major source of environmental degradation, and suggesting instead that both poverty and environmental degradation result largely from wealth. It next examines the concepts of natural capital and social capital, whether (and if so, how) they are linked, and explores their implications for sustainable development at the community level.

In Chapter 3 we examine planning theory and sustainable development, asking whether planning theory is relevant to sustainable development, and investigating Friedmann (1987)'s four traditions of planning theory. It finds that while planning theory is, or should be, relevant to sustainable development, planners concerned with key aspects of sustainable development will have to look to "greener" pastures for relevant theoretical guidance. It continues with an exposition of what arguably is, or ought to be, a "fifth tradition" in planning theory, one which can help planners grapple with some tremendously important issues that are otherwise usually addressed inadequately or ignored completely in regard to sustainable development. This survey of the paradigms associated with healthy 
communities, appropriate technology, social ecology, the green movement, bioregionalism, and native worldviews implies that planning theory educators should re-evaluate their syllabi to expose their students to this body of literature.

Chapter 4 considers the implications for achieving sustainable development in communities, particularly regarding the future of work and community economic development. It is informed by four arguments which, taken together, indicate that we must explicitly aim to nurture and multiply social capital in order not only to preserve our stock of natural capital but also to improve our economic and social well-being.

Chapter 5 details a framework for sustainable community development. It begins by elaborating the concept of a sustainable community, examines distinctions relevant to communities in developed and developing parts of the world, proceeds to investigate some of the reasons why North American communities are presently unsustainable, explores some characteristics of more sustainable communities, and concludes with the role of citizens and their governments in moving toward sustainable communities. Applying the concept of sustainable development to North American communities begins with unprecedented and simultaneous emphasis on the efficient use of urban space, on minimizing the consumption of essential natural capital, on multiplying social capital, and on mobilizing citizens and their governments toward these ends. This last element is crucial to co-ordinating and balancing the other three.

Chapter 6 concerns questions of governance for sustainable community development. It explores both governance and government in this context. In particular, it focuses on public participation, decision-making, the role of local government, and planning for action.

Chapter 7 examines relevant policy instruments and planning tools. The policy instruments are presented in four categories: traditional regulations such as permits and licenses that have a legal basis; voluntary mechanisms or actions taken that generally do not require expenditure; direct government expenditure such as money spent on improved infrastructure; and financial incentives such as taxes, subsidies, tradable permits, and rewards. The planning tools are organized into planning tools and assessment tools, and further organized into community planning and assessment tools and technical planning and assessment tools.

Finally, Chapter 8 explores the challenge ahead for sustainable community development. In summary, this article aims to develop a framework which could itself contribute to sustainable community development. It attempts in part to bridge the gap between traditional community development concerns (of e.g. local decision-making and selfreliance, co-operative endeavour and broad participation in community affairs) with more recent global sustainability concerns. It illustrates the implications of this framework for governance, and demonstrates that a wide range of policy instruments and planning tools now exist which can be used to implement the framework.

This introduction concludes with a comment on the presentation of the research in this article. The information employed in the study consists of case studies and examples of specific municipal and local government initiatives related to sustainable development, but no single detailed case study is presented as the focus of an entire chapter. This is quite deliberate, since the purpose of the work is to view a broad set of topics holistically so as to develop an understanding of the implications of sustainable development per se at the community level. 


\section{CHAPTER 2}

\section{Sustainable development: an overview}

As we enter the new millennium it has become clear that human activity has damaged the natural integrity of major ecosystems on every continent, seriously threatening the security of the societies that depend on these ecosystems (e.g. Brown et al., 1998). Moreover, the most worrisome environmental trends are global in scope, and thus threaten all of humanity. As many international gatherings have agreed:

The best predictions available indicate potentially severe economic and social dislocation for present and future generations, which will worsen international tensions and increase risk of conflicts between and within nations.*

In 1987 the World Commission on Environment and Development (WCED) report Our Common Future brought the concept of "sustainable development" squarely into the purview of governments and publics around the world. $\dagger$ This global audience has pinned its hopes to sustainable development as a solution to urgent environmental and societal problems where business-as-usual has failed.

The mainstream view of the environment today is sharply different from what it was twenty years ago, when environmental problems were almost universally regarded as minor, technical, soluble, and politically uncontentious. They were considered byproducts of economic growth and social progress which further applications of growth and progress would duly solve, as increasing wealth created the resources and improved technology the means to solve them.

Today, throughout the industrialized world, governments and parties of both left and right now acknowledge that environmental problems are indeed very serious, requiring solutions which are not merely technical, and which may not be available at all without significant social and economic change. The vehicle for this shift has been the concept of sustainable development, which has succeeded in overcoming the conflict between environmental protection and economic growth, which characterized the environmental debate of the 1970s and early 1980s. It accepts that protecting the environment requires fundamental change in the direction of economic progress and the institutions of government policy. But it argues that this is compatible with continued economic growth in a (regulated) global capitalist system. In this sense, sustainable development represents a "historic compromise" between the ideology of capitalism and its environmental critique, and which has enabled a single environmental discourse to develop, used by all manner of governments, business organizations, and environmental organizations (Jacobs, 1997).

In the context of other significant global reports on the environment over the last few decades (e.g. Limits to Growth, Global 2000), a major contribution of the World

\footnotetext{
*Conference Statement, The Changing Atmosphere: Implications for Global Security, Toronto, Ontario, 27-30 June 1988.

$\lceil$ The term sustainable development dates back at least as far as the World Conservation Strategy (IUCN, 1980), and its conceptual precursors linking environment and development (e.g. ecodevelopment) have received international attention at least since the United Nations Conference on the Human Environment in 1972.
} 
Commission was its explicit recognition that poverty is a major source of environmental degradation.* For example, the collection and use of firewood by families in developing countries is sometimes considered a major reason for deforestation. While this connection may seem reasonable enough at first glance, the main causes of deforestation are actually large-scale lumbering, agricultural expansion, overuse of existing agricultural land, burning of forests to encourage fodder growth, over-grazing and rapid urban growth (Pietila, 1990).

Although the Commission provided no analysis of the causes of poverty, it's concern about poverty lead it to the argument that economic growth must be stimulated. However, the major flaw of the Commission's analysis (and the likely reason Our Common Future has been embraced by governments and corporations as much as by environmentalists) is that it downplays the extent to which both poverty and environmental degradation result from wealth.

The threat of atmospheric change, for example, clearly illustrates the role of wealth in global environmental damage. Fossil-fuel-based carbon emissions (e.g. carbon dioxide) are a leading source of atmospheric and potential climate change (e.g. global warming). The wealthy, energy-intensive quarter of the world's population is responsible for nearly $70 \%$ of these carbon emissions. It is a simple fact of atmospheric science that the planet will never be able to support a population of 8 billion people generating carbon emissions at even the rate of Western Europe today. Yet, North Americans generate carbon emissions at twice the rate of Western Europeans (Flavin, 1990).

Some critics (e.g. Trainer, 1990) were dismayed that the Commission chose economic growth and all its attendant social and environmental impacts (e.g. its tendency to exploit both labour and the environment) over a consciously appropriate development strategy for the Third World (e.g. adequate housing and clean water rather than export plantations and automobile factories). For others, the principal weakness of Our Common Future is that its call for growth was addressed not only to the developing countries but also to the industrialized countries. The Commission went so far as to call for a five- to ten-fold increase in world industrial output - without any analysis to show whether such economic expansion is ecologically possible (Rees, 1992a,b) $\dagger$ Ecological footprint analysis (Wackernagel and Rees, 1996) indicates that such economic expansion would require at least two additional planet Earths to produce the resources, absorb the wastes, and otherwise maintain lifesupport.

Canada's official response to Our Common Future typifies the mainstream interpretations of sustainable development. It states that "sustainable economic development does not require the preservation of the current stock of natural resources or any particular mix of human, physical and natural assets. Nor does it place artificial limits on economic growth, provided that such growth is both economically and environmentally sustainable"

\footnotetext{
*In the words of the Brundtland Commission, “... poverty itself pollutes the environment... Those who are poor and hungry will often destroy their immediate environment in order to survive... poverty itself is a major global scourge" (WCED, 1987: 28).

$\dagger$ The Commission called for a "new era of growth," by which is meant "more rapid economic growth in both industrial and developing countries, freer market access for the products of developing countries, lower interest rates, greater technology transfer, and significantly larger capital flows" (WCED, 1987: 89).
} 
(National Task Force on Environment and Economy, 1987). In the debate over the meaning of sustainable development, this mainstream view has come under increasing scrutiny.

\subsection{Natural capital and social capital: implications for sustainable development*}

Two of the most intriguing ideas to hit academic journals in recent years are natural capital and social capital. Natural capital is a term used primarily by ecological economists, themselves a relatively new breed, to further our understanding of sustainable development (e.g. Jansson et al., 1994; Wackernagel and Rees, 1996). Social capital is a term used by progressive economists and other social scientists to further our understanding of society and community (e.g. Jacobs, 1961; Coleman, 1988; Ostrom, 1993; Putnam, 1995).

This chapter will examine the concepts of natural capital and social capital, whether (and if so, how) they are linked, and explore their implications for sustainable development.

\subsubsection{Natural capital}

Global resource depletion and pollution are forcing recognition that existing patterns of development and resource use are not sustainable. Even conservative neoclassical economists are recognizing that the "sustainable" component of development requires that human activities today do not deplete what can be termed "natural capital" or "environmental capital." Natural capital refers to any stock of natural assets that yields a flow of valuable goods and services into the future. For example, a forest, a fish stock or an aquifer can provide a harvest or flow that is potentially sustainable year after year. The forest or fish stock is "natural capital" and the sustainable harvest is "natural income."

The total stock of environmental assets that comprise this natural capital may usefully be divided into three categories:

- non-renewable resources, such as minerals and fossil fuels;

- the finite capacity of natural systems to produce "renewable resources" such as food crops, forestry products and water supplies - which are renewable only if the natural systems from which they are drawn are not overexploited; and

- the capacity of natural systems to absorb the emissions and pollutants which arise from human actions without side effects which imply heavy costs passed onto future generations (such as activities that release chemicals which deplete the atmosphere's ozone layer and greenhouse gases which may cause serious climatic imbalances).

Natural capital also provides such critical ecological services as waste assimilation, erosion and flood control, and protection from ultraviolet radiation (the ozone layer is a form of natural capital). These life support systems are counted as natural income. Since the flow of services from ecosystems often requires that they function as intact systems,

\footnotetext{
*An earlier version of this chapter appeared in Roseland, M., Natural Capital and Social Capital: Implications for Sustainable Community Development. Community Perspectives on Sustainable Development, Pierce, J.T. and Dale, A. (ed.), University of British Columbia Press, Vancouver (1999, pp. 190-207).
} 
the structure and diversity of the system may be an important component of natural capital (Wackernagel and Rees, 1996).

Although natural capital is a relatively new way of framing choices for social policy and action, it has helped considerably to refine the sustainability debate. For example, there is no doubt that the stock of non-renewable resources are finite, nor is there any doubt that eco-systems (individually and collectively within the biosphere) have limits in their capacity to absorb pollutants. There is also agreement that some environmental assets, such as areas of outstanding natural beauty, are irreplaceable. "The debate centres on which environmental assets are irreplaceable and the extent to which current (and projected) future levels of resource use degrade the capital stock of environmental assets for future generations, the extent to which one resource can be substituted for another (for instance, a synthetic substance replacing a natural one) and the extent to which pollutants derived from human activities are damaging the biosphere" (Mitlin and Satterthwaite, 1991).

2.1.1.1. Two interpretations of sustainability. Pearce et al. (1989) argue that "future generations should be compensated for reductions in the endowments of resources brought about by the actions of present generations," suggesting that each generation should leave the next a stock of assets at least as great as that which they inherited themselves. There are two possible interpretations of this condition: "weak sustainability," which aggregates all types of assets, and "strong sustainability," which differentiates between assets which are "natural" and those which are not, arguing that whatever the level of human-made assets, an adequate stock of environmental (or natural) assets alone is critical in securing sustainability (Daly, 1989).

The weak sustainability interpretation reflects the neoclassical economic assumption that natural and non-natural assets are substitutable and that natural assets can be liquidated as long as subsequent investment provides an equivalent endowment to the next generation (Rees, 1992a,b). Yet in some cases, natural and non-natural assets are clearly not substitutable. For example, a sawmill cannot be substituted for a forest since the sawmill (non-natural capital) needs the forest (natural capital) in order to function (Daly, 1989).

The weak sustainability interpretation also assumes that other forms of capital (e.g. manufactured, financial, or human capital) can be converted back into natural capital. This interpretation does not take into account irreversible processes such as the extinction of species or the destruction of ecosystems.

All this suggests that the weak sustainability interpretation is grossly insufficient; even Pearce et al. agree that natural capital stock should only be destroyed if the benefits of doing so are very large or if the social costs of conservation are unacceptably large (Pearce et al., 1990). Yet this begs the key question: are we capable of knowing the social costs and benefits of destroying or conserving natural capital stock? Ecological economists can put a price on resources such as timber and fisheries; but the value of ecological process resources such as carbon absorption or photosynthesis cannot easily be quantified and monetized (Rees, 1991).

The very concept of econonomic "trade-offs" depends upon being able to put a price on the items traded. Resources that cannot be quantified or monetized also cannot be priced. It 
may be theoretically possible to trade-off some value of a fishery for some value of a timber harvest, but it may not be possible to price the value of the ozone shield.

The economic benefits of destroying natural capital stock or the social costs of conservation may seem large, but only as a function of our inability to adequately assess such costs and benefits. So-called rational economic analysis has extended beyond its rational limits (Rees, 1991). This suggests that it is time for a different kind of framework for planning and decision-making, guided by the understanding that natural capital stock should not be destroyed.

The pace of global ecological change suggests that human activity may already be undermining essential ecosphere functions. In these circumstances, it would be a 'sound risk-averse strategy' for society simply to accept, that while technically inestimable, the life support values of remaining stocks of natural capital are greater than any stock-depleting development values however large the latter might be. Given the threat to global security associated with irreversible disruptions of the ecosphere, and the increasing probability of such events under prevailing development approaches, we are confronting a category of strong catastrophic risk which 'should, in the limit, not be undertaken at any price.' In short, if the potential benefits of conservation can be shown to approach infinity, the costs are irrelevant... (Rees, 1991).

In terms of the life-support functions of natural capital, destruction of any single significant natural asset can be likened to destruction of any single bodily organ or system. The destruction of the ozone layer may have the same consequences, in planetary terms, as destruction of the immune system has for the human body; global warming may be analogous to a high fever.

We do not ask those who suffer from heart disease to "trade" normal brain functioning for a healthier heart. Such choices are the stuff of literature's great tragedies; they only become more tragic if we insist upon this approach to deciding complex societal choices.

Like a thermometer registering a fever, the accumulating trends of ecological decline (e.g. decrease in stratospheric ozone, increase in greenhouse gases, extinction of species, loss of biodiversity, etc.) are the indicators of our condition.

The ecological bottom line for sustainable development can be stated as an economic metaphor: humankind must learn to live on the 'interest' generated by remaining stocks of living 'natural capital.' Any human activity dependent on the consumptive use of bioresources cannot be sustained indefinitely if it not only consumes annual production, but also cuts into capital stocks* (Rees, 1991).

To summarize, sustainability requires maintaining an adequate per capita stock of environmental assets for use by future generations and avoiding irreversible damage to any single significant asset. $\dagger$

\footnotetext{
*Rees (1991) also notes that "this shifts the emphasis of environmental policy from pollution control ... to managing consumption. In thermodynamic (rather than mechanical) terms, all material economic production is actually consumption."

$\dagger$ The phrase "adequate per capita stock of environmental assets" is used advisedly. Some authors (e.g. Mitlin and Satterthwaite, 1991) use the phrase "a constant stock of environmental asssets"; however, the stock would only remain "constant" if populations and living standards also remained constant.
} 


\subsubsection{Social capital}

Ostrom (1993) notes that all forms of capital are created by spending time and effort in transformation and transaction activities. Physical capital is the stock of material resources that can be used to produce a flow of future income. The origin of physical capital is the process of spending time and other resources constructing tools, plants, facilities, and other material resources that can, in turn, be used in producing other products. Human capital is the acquired knowledge and skills that individuals bring to productive activity. Human capital is formed consciously through training and education and unconsciously through experience.

The first significant appearance of the concept of social capital was in the work of Jacobs (1961), where she used it to describe a norm of social responsibility, a corresponding atmosphere of social trust and interconnecting networks of communication.

Social capital is the shared knowledge, understandings, and patterns of interactions that a group of people bring to any productive activity (Coleman, 1988; Putnam et al., 1993). Social capital refers to the organizations, structures and social relations which people build-up themselves, independently of the state or large corporations. It contributes to stronger community fabric, and, often as a by-product of other activities, builds bonds of information, trust, and inter-personal solidarity (Coleman, 1990).

The term social capital refers to features of social organization such as networks, norms, and trust that increase a society's productive potential (Putnam et al., 1993). Though largely neglected in discussions of public policy, Putnam argues that social capital substantially enhances returns to investments in physical and human capital. However, unlike conventional capital, social capital is a public good, i.e. it is not the private property of those who benefit from it. Thus, like other public goods, from clean air to safe streets, social capital tends to be under-provided by private agents. The ties, norms and trust that constitute social capital are most often created as a by-product of other social activities and then transferred from one social setting to another.

Social capital is created when individuals learn to trust one another so that they are able to make credible commitments and rely on generalized forms of reciprocity rather than on narrow sequences of specific quid pro quo relationships. Ostrom (1993) notes that the shared cognitive aspects of social capital help account for two unusual characteristics that differ from physical capital:

First, social capital does not wear out upon being used more and more... Using social capital for an initial purpose creates mutual understandings and ways of relating that can frequently be used to accomplish entirely different joint activities at much lower start-up costs... Social capital that is well adapted to one broad set of joint activities may not be easily molded to activities that require vastly different patterns of expectation, authority, and distribution of reward and costs than used in the initial sets of activities.

Second, if unused, social capital deteriorates at a relatively rapid rate. Individuals who do not exercise their own skills can lose human capital relatively rapidly. When several individuals must all remember the same routine in the same manner, however, the probability that at least one of them forgets some aspect increases rapidly over time. Further, as time goes on, some individuals leave and others enter 
any social aggregation. If newcomers are not introduced to an established pattern of interaction as they enter (through job training, initiation, or any of the myriad other ways that social capital is passed from one generation to the next), social capital can dissipate through nonuse; no one is quite sure how they used to get a particular joint-activity done. Either the group has to pay some of the start-up costs all over again, or forego the joint advantages that they had achieved at an earlier time.

Social capital differs from other forms of capital in several significant ways, one of which is that it is not limited by material scarcity, meaning that its creative capacity is limited only by imagination. It thereby also suggests a route toward sustainability, by replacing the fundamentally illogical model of unlimited growth within a finite world, with one of unlimited development* which is not bound by the availability of material resources.

However, social capital also has limitations that other forms of capital do not. It cannot be created instantly, and the very fact of trying to consciously create it or direct it can create resistance. People resist being instrumentalized for even the best of reasons. Social capital takes time to develop, and is inherently non-transferable (Flora and Flora, 1993). It is also fragile and subject to erosion not only by direct assault but more importantly, by neglect, if there are many or strong competing attractors for investment of emotional significance or time.

The modern conceptualization of social capital is associated with Coleman (1988), who describes it as the relations between individuals and groups. It can take several forms, some of which are mutually recognized bonds, channels of information, and norms and sanctions. In this sense social capital is related to the concept of social ecology discussed later (Bookchin, 1987). The value of the concept, for Coleman, lies in the fact that it identifies aspects of the social structure by their functions. "The function identified by the concept of 'social capital' is the value of these aspects of the social structure to actors as resources that they can use to achieve their interests" (Coleman, 1988).

2.1.2.1. Measuring social capital. An obvious question about social capital is whether and how it can be measured. For example, Putnam (1995) argues that US social capital is declining. Putnam's "Bowling Alone," published in the January 1995 issue of the Journal of Democracy, has had an impact far beyond the usual for academic writing. The thesis of "Bowling Alone" is that the vibrancy of American civil society "has notably declined over the past several decades." Putnam gets his title from the finding that from 1980 to 1993 the league bowling declined by $40 \%$ while the number of individual bowlers rose by $10 \%$. The rest of his evidence is less whimsical: voter turnout, church attendance, and union membership are down. The percentage of people who trust government and who attend community meetings has dropped, and membership in voluntary associations is down by roughly one-sixth from 1974 to 1989.

The significance of these changes, for Putnam, is not that they are inherently unfortunate so much as that they predict a broader decline in our society's economic vitality. Other

\footnotetext{
*As discussed later, "development" can be described as a social change process for fulfilling human needs, advancing social equity, expanding organizational effectiveness, and building capacity toward sustainability.
} 
analysts (e.g. Rose, 1996) concur that the wealth of nations is likely to be highest where there is a large stock of social capital.

In "Kicking in Groups," Lemann (1996) wonders aloud why Putnam's thesis that civic virtue is rapidly collapsing in the US is being "so widely and instantly accepted as gospel." Lemann investigated several potential replacements for bowling leagues, and found, for example, that the American Association of Retired Persons has 33 million members; US Youth Soccer has 2.4 million members, up from 1.2 million ten years ago; individual donations to charity grew from US\$ 16.2 billion in 1970 to 101.8 billion in 1990; Little League membership has increased every year; and PTA membership has risen over the past decade.

In Canada, the number of charitable organizations registered with Revenue Canada more than tripled between 1967 and 1994, going from 22556 to 71414 . Under federal law, registered charities are defined as non-profit organizations established for the "relief of poverty, the advancement of religion, the advancement of education, and other purposes beneficial to the community as a whole, in a way which the law regards as charitable." Revenue Canada classifies them under six broad categories: welfare, health, education, religion, benefits to the community, and other. Religious charitable organizations comprise the largest single group (42.3\%), followed by welfare $(17.3 \%)$, benefits to the community (17.0\%), education (16.0\%), and health $(7.3 \%)$ (Browne, 1996: 21-22).

Rose (1996) cautions that the number of formal organizations in a society, especially national organizations, is not an adequate indicator of social capital. Members of many organizations are not individuals but other organizations. Even when individuals are the constituent members, the number varies from one social activity to another, and so does the extent to which an association includes a high percentage of its potential members. Furthermore, people can put their name on a membership list without attending meetings of their organization. The fundamental limitation of data about formal organizations is that it ignores informal social networks important in every society.

To use an instrumental definition, social capital gets created by the individuals who form social networks, to produce goods and services, non-monetized as well as monetized. Networks are usually informal groups of people who know each other personally, such as villagers who help each other at harvest time or friends and neighbours who help each other cope. "Even if networks have a formal institutional identity, such as a choir society or a rural co-operative, they remain face-to-face groups in which the reputation of individuals is known to its members. Informal face-to-face networks can be found not only in villages and urban neighbourhoods but also among economic and policymaking elites" (Rose, 1996).

Social capital can add to human capital - e.g. social networks provide many informal types of social security and health care to individuals within a collective "caring" network. It can also add to natural capital-e.g. enhancing the use of natural resources, such as water for irrigation systems, requires collective action.

Social capital can take negative as well as positive forms. Development of natural resources can reduce the stock of social capital if, for example, villages are flooded and the social networks of the residents are broken up. Social capital can also distort the rule-bound market allocation of goods and services, as in Mafia-type groups selling 
"insurance" to firms. In extreme cases, social capital can impose losses on individuals, such as when a strong social network effectively prevents girls from getting an education and employment (Rose, 1996).

2.1.2.2. Social capital and social networks.* Coleman (1988) differentiates social networks into those with and without closure, and uses the difference to explain the presence or absence of social norms and their effectiveness or lack of it. A network with closure is one where most of the individuals within it know each other, and the relationship of each to the others. Networks with closure can be highly effective at enforcing norms, but as discussed earlier, the results can be positive or negative. Coleman uses the example of parents of students in a religious school, but a prison demonstrates the same principle at work.

A network without closure is one where each individual's circle of acquaintances overlaps only partially or not at all with those of the others, and the degree of overlap is generally unknown. These networks can only weakly enforce informal norms and are forced to rely on formal structure - courts, police, lawsuits - to a much higher degree than networks with closure.

Coleman (1988) observes that the public goods quality of most social capital means that it is in a fundamentally different position with respect to purposive action than are most other forms of capital. Since the benefits that the actions which bring forth the social capital into being are largely experienced by persons other than the actor, it is often not in the actor's interest to bring it into being. The result is that most forms of social capital are created or destroyed as by-products of other activities.

Another significant point about social capital is that because it is located in relationships with specific individuals, social capital that is mobilized for one purpose can be readily appropriated for other purposes.

Beyond understanding the basic nature of social capital, for sustainable community development one needs to know where it is located and how it can be mobilized and multiplied.

2.1.2.3. Locating social capital. Formally organized groups are the necessary recourse of societies without closure. Organized groups have established procedures for adherence and keep membership lists, follow recognized procedures to conduct their affairs, and often administer budgets and own property. Examples are churches, ethnic associations, trade unions, associations, sports associations, theatre societies or environmental groups. However, a formal organization may also be a public representation of a more primary closure society. Churches, especially ethnically rooted ones, tend to fall into this category. Organizations that have survived an intense struggle in a hostile social environment, such as some unions and environmental groups, can also take on something of this character of closure.

Informal groups can be regular customers of a shop, users of a park, sports fans, music fans, mothers of children who play together, or groups of street youth who mutually protect each other. Members of such groups may not necessarily know each other, or

*I am grateful to Joan Fletcher for much of the analysis in this chapter. 
even that they constitute a group, yet they can be a useful resource for each other, and an immense reservoir of energy and imagination if it can be accessed and organized.

2.1.2.4. Mobilizing and multiplying social capital. Mobilization and the use of social capital are not without their problems. By its very nature, social capital can tend to mirror existing power structures. Marginalized people are sometimes marginalized exactly because they are unable to access social capital, as is often the case with the mentally ill or other people with poor social skills.

Even in a society with closure, social capital may be divided among different factions who regard each other as rivals or threats. While there are possible tools to deal with this, their success is uncertain, and the difficulties are worse in situations like larger Canadian cities, where there are many groups competing with others without closure, who may not even be able to communicate because of language barriers. This is not to claim that we should give up on prospects for sustainable community development in urban centres, but rather that we should not deceive ourselves about the challenge involved.

If social capital is important, then classic liberal social policy, with its emphasis on enhancing the opportunities of individuals, is partially misplaced. Instead, argues Putnam et al. (1993), we must focus on community development, allowing space for religious organizations, choral societies, and Little Leagues. Whatever their intended effects, government policies should be vetted for their indirect effects on social capital. Government investment in social capital, from agricultural extension services to tax exemptions for community organizations, must be renewed and encouraged.

The role of education in facilitating social capital must also be reconsidered. Education should attempt to create integrated opportunities for both individual and collective learning, and students should understand and experience learning communities and learning organizations (e.g. Schon, 1983; Boggs, 1990; Senge, 1990; Hamilton, 1992).

\subsubsection{Linking natural capital and social capital}

From a sustainable development perspective, we must re-interpret our classical understanding of wealth and capital in terms of satisfying fundamental human and ecological needs. Thus, natural capital, human capital, social and organizational capital, and manufactured capital all contribute to the creation of "wealth" in its broadest sense (Ekins, 1986).

Community "civicness" is key to maximizing the potential of communities as agents of sustainable development (Selman and Parker, 1997). Putnam et al. (1993) suggests that civicness in a community will lubricate social life, enhance productivity and facilitate action; in practice, it will then become a proxy for successful policy implementation. It is also an important component of sense of place, which many authors have identified as critical for community sustainability (e.g. Sale, 1985; Hiss, 1990; Aberley, 1993, 1994; Roseland, 1997).

According to the UBC Task Force on Healthy and Sustainable Communities, along with ecological carrying capacity, we also need an increase in the "social caring capacity" (SCC) of our communities (UBC Task Force on Healthy and Sustainable Communities, 1994). SCC, reflected by networks of social capital, is the prerequisite for sustainable development. Evidence from the Indian state of Kerela (McKibben, 1996) suggests that 
quality of life can increase while industrial throughput decreases;* i.e. social capital can substitute for manufactured capital. Furthermore, whereas natural capital diminshes with exploitation, social capital accumulates with regular use (Selman and Parker, 1997).

2.1.3.1. Social infrastructure and sustainable personalities. Flora and Flora (1993) have identified "social infrastructure" as the key to linking individual leadership to physical infrastructure and to facilitating community development. Social infrastructure is the group-level, interactive aspect of organizations or institutions. Swanson (1992) conceptualizes social infrastructure as having three parts: (1) social institutions, including local government, social service institutions, voluntary and civic organizations, and the like; (2) human resources, which include attributes of inhabitants such as their technical expertise, organizational skills, educational levels, and even social structure - class, race, ethnicity, gender, and so on; and (3) characteristics of social networks, including innovativeness, ability to mobilize resources within the community, ability to link up with outside expertise and information, and so on.

In the context of the Local Agenda 21 initiatives now being widely produced throughout Britain, Selman and Parker (1997) have identified three types of person - not mutually exclusive - that are essential to successful sustainable development processes at the community level. They argue that it is overwhelmingly important that strategies seek to ensure that the energies of these people are nurtured, stewarded, and sustained.

First are the "catalytic personalities," whose elemental presence speeds up the rate of a reaction in the social chemistry of community change. While often thought to emerge spontaneously from the local community, they are actually often present in various quarters, including the civil service, local government and public agencies. They are willing and able to, enthusiastically, see a project through from conception to completion. They are also subject to feeling burned-out, exploited, or disillusioned, and if they leave in the course of a project it can result in a disastrous loss of momentum.

Second are "community champions," spokespeople who represent the views and interests of the community, often with unwelcome force, to otherwise impervious bureaucracies.

Third are the "supernetworkers." While the role of networking is well established in community work, many people are not interested in, or able to comprehend, more than one aspect of sustainable development. Supernetworkers have the imagination, interest, time and energy to take an active role in co-ordinating groups, and to liase with several parallel streams of interest. They not only underpin strategy synthesis, but they also typically bring their personal networking skills to bear on the mobilization of financial and personnel resources.

2.1.3.2. Implications for development. Critics of the development system (e.g. Gran, 1987) define development as "a social change process that involves four basic elements:

\footnotetext{
*Kerala, a state of 29 million people in southern India, has a per capita income estimated by various surveys to be between US\$ 298 and 350 per year, about one-seventieth the US average. Yet data for life expectancy, literacy, and birth rates for Kerala are comparable to those for the US. "One-seventieth the income means one-seventieth the damage to the planet. So, on balance, if Kerala and the United States manage to achieve the same physical quality of life, Kerala is the vastly more successful society" (McKibben, 1996).
} 
advancement in material or service output (the growth factor); equitable spread and equity of benefits among participants; expansion of organizational effectiveness; and capacity building toward sustainability."

Democracy is an inherent part of the process. If we can end monopoly of economic, political or cultural resources, then equity, sustainability, efficiency and the environment all gain. Development so defined is participatory development; for people to prosper anywhere they must participate as competent citizens in the decisions and processes that affect their lives. Development is thus about the quantity and quality of empowerment and participation of people... Development so defined is not the purview of neoclassical economists. Indeed they are a large part of the problem (Gran, 1987).

For our purposes, the "development" component of sustainable development can be described as a social change process for fulfilling human needs, advancing social equity, expanding organizational effectiveness, and building capacity toward sustainability.

The latter two elements are self-explanatory. Human needs, in this context, refer to both material and non-material needs. Material or basic needs include those physical necessities of life such as adequate food, water, and shelter. Non-material needs relate more to broader "quality of life" issues such as health; political and spiritual freedom; human rights; clean, healthy and accessible natural environments; and meaningful work. Social equity includes both future (intergenerational) and current equity. Future equity depends largely upon achieving sustainability, i.e. maintaining ecological integrity. Current equity refers to the relations between the Industrialized Minority — the world's affluent - and the world's poor, both between and within countries; it requires not only maintaining ecological integrity but also meeting the full range of human needs, expanding organizational effectiveness, and building capacity toward sustainability.

The goals of this process can initially be taken as those contained in the United Nations Universal Declaration of Human Rights. Article 25, Section 1, reads: "Everyone has the right to a standard of living adequate for the health and well-being of himself and his [sic] family, including food, clothing, housing and medical care and necessary social services, and the right to security in the event of unemployment, sickness, disability, widowhood, old age or other lack of livelihood in circumstances beyond his [sic] control" (quoted in Sieghart, 1986). Most western observers would also insist that the right to vote within representative government structures be considered a minimum requirement of any development strategy. 


\section{CHAPTER 3}

\section{Is planning theory relevant to sustainable development?}

In light of the preceding discussion, what can sustainable development proponents and practitioners hope to learn from planning theory? The answer depends largely upon: (1) how sustainable development is interpreted; and (2) how planning theory is interpreted.

As discussed above, the range of definitions, or interpretations, of sustainable development is quite broad. Like sustainable development, planning theory also suffers from an abundance of interpretation. There may well be as many definitions of planning theory as there are planning theorists. It is not the purpose of this discussion to go into an extensive discussion of what constitutes planning theory, but the subject of our inquiry demands that the question be addressed. A highly regarded planning theorist (Burchell, 1988) describes the field as follows:

Planning theory ... is a theory represented by a procedural rational model that is both simultaneously under attack yet re-emerging as a defaultingly accepted explanatory structure for the actions of practitioners.

The planning field has responded to the breakdown of the rationality model in four different ways (Alexander, 1988): (1) the ritual response - not recognizing the breakdown and clinging instead to the old model; (2) the avoidance response - usually involves a substitution of other, more descriptive decision-making models; (3) the abandonment response* - which rejects both the rational model and any other similarly general construct as unnecessary; and (4) the search response - which offers other, more radical models as replacements for the rational paradigm.

John Friedmann's 1987 treatise, Planning in the Public Domain (Friedmann, 1987), currently the major text in planning theory, takes a broad view of the field:

The major object of planning theory is to solve the "meta-theoretical problem of how to make technical knowledge in planning effective in informing public actions".

Focusing on the link between knowledge and action, Friedmann argues (p.39) that "a comprehensive exploration of the terrain of planning theory must cull from all the relevant disciplines those elements that are central to an understanding of planning in the public domain." $\dagger$

Friedmann has framed two centuries of planning theory into four traditions. Social Reform and Social Mobilization, the two older traditions, reach back to the first half of the nineteenth century. Policy Analysis and Social Learning originated in the period between the Great Depression and World War II. Friedmann contends that depending

\footnotetext{
*An example of the abandonment grouping is this statement that “...we do not need a complete general theory of planning and we do not even need to agree on the definition of the field" (Mandelbaum, 1988).

$\dagger$ Friedmann offers three conceptual definitions of planning. Planning attempts to link scientific and technical knowledge either: (1) to actions in the public domain; (2) to processes of societal guidance; or (3) to processes of social transformation (pp. 38-39). These definitions, which emerge from one of the four historical traditions of planning thought, lead to very different choices for planning action.
} 
Table 1

The four traditions of planning theory

Social reform: includes the disciplines of sociology, institutional economics, and pragmatism. It recognizes the state as the vehicle of social action. Planning is a scientific endeavor to make state action more effective. The economy can be adjusted to serve representative needs through business-cycle analysis, input/output analysis, economic policy models, and others.

Policy analysis: includes the disciplines of systems analysis, welfare and social choice, and policy science. It concentrates on decision making as a means of identifying the best possible courses of social action. Planning is a decision process which emphasizes stages that begin with the identification of goals that will structure the decision and ends with program analysis, which evaluates the correctness of the decision. This is the rational model participated in by technical planners who view themselves as social engineers serving the existing power base.

Social learning: includes the field of organization development. It is an effort to minimize the contradictions between what we know and how we act. Planning attempts through social experimentation to change social behaviour. This is accomplished by doing: knowledge is validated practice, and theory is enriched from lessons learned from experience. Planners and client actors are involved in nonhierarchical exchanges of information to further learning.

Social mobilization: includes neo-Marxism, the Frankfurt School (of critical theory), and a category Friedmann calls utopians, social anarchists, and radicals. It is a view of the primacy of action from below. Planning is a political activity which attempts to change the status quo of oppression and alienation under capitalism. Social mobilization emphasizes the politics of disengagement and confrontation. The planner's role is one of community organization, advocacy presentation and interpretation of data, and representation within and cooptation of the decision-making process.

upon education, tasks, and predilection, planners can identify who they are or their resultant efforts through one of these traditions (see Table 1).*

The knowledge that we must act to achieve a more sustainable form of development has been with us for many years. But the great question that plagues sustainable development proponents is how do we achieve sustainable development, or, in the language of planning theory, how should this knowledge properly be linked to action? If we accept that this question, of knowledge and action, is the core concern of all the traditions of planning theory (Friedmann, 1987: 73-74), then planning theory by definition is, or should be, relevant to sustainable development.

By this point, however, it is also apparent that the question we are attempting to answer, is planning theory relevant to sustainable development? is of little value in its present form. Familiarity with planning theory leads instead to the question, which planning theory traditions are relevant to sustainable development? Familiarity with sustainable development, on the other hand, leads to the question, which concerns of sustainable development are relevant to planning theory? Our question, then, ought to be stated thus: which planning theory traditions are relevant to which concerns of sustainable development?

Sustainable development per se has only recently emerged as a distinct subject of inquiry; therefore it remains to be seen how planning theory can contribute to it. We can, however,

*These summaries of Friedmann's traditions are adapted from Burchell (1988). 
examine which planning theory traditions historically offer the most guidance for sustainable development concerns, an exercise that reveals three interesting points.

Firstly, the most conventional, narrow interpretations of sustainable development primarily emphasise fulfilling material human needs, maintaining environmental assets for future generations (e.g. conservation), and future equity. The most relevant planning theory traditions from this perspective, social reform and policy analysis, have much to offer in regard to fulfilling material human needs, but are virtually mute on all the other sustainable development components discussed above: advancing social equity, maintaining environmental assets for future generations, avoiding irreversible damage to any single significant asset, expanding organizational effectiveness, and building capacity toward sustainability. Given that social reform and policy analysis are the two dominant traditions in planning theory (constituting the heart of the "rational paradigm"), we can begin to see why planning theory has been slow to identify sustainable development concerns and give them appropriate prominence.

Secondly, only the social learning and social mobilization traditions - not the dominant traditions in planning theory - offer guidance in regard to current equity, expanding organizational effectiveness, and building capacity.

Thirdly, despite the dimly-acknowledged contributions of the social learning and social mobilization traditions, there are still significant gaps in planning theory as it pertains to sustainable development, especially in the areas of future equity, building capacity toward sustainability, maintaining environmental assets for future generations, and avoiding irreversible damage to any single significant environmental asset. Planners concerned with these aspects of sustainable development will have to look to "greener" pastures for relevant theoretical guidance. "Fortunately, there is no shortage of 'unscientific' (but otherwise rational) concepts relevant to sustainable development. Authors in many disciplines have begun to articulate new worldviews and development principles that transcend the conventional emphasis on hard technology, material growth, and the marketplace as the wellspring of all social value" (Rees, 1992a,b).

\subsection{The "fifth tradition" in planning theory}

The analysis so far has demonstrated that the four traditions of planning theory are weak in regard to sustainable development, and in particular to the areas of future equity, building capacity toward sustainability, maintaining environmental assets for future generations, and avoiding irreversible damage to any single significant environmental asset. Fortunately, there is a "fifth tradition" in planning theory (or deserving admission into planning theory) which can help planners grapple with these tremendously important issues.

Here is a brief survey of the paradigms associated with healthy communities, appropriate technology, social ecology, the green movement, bioregionalism, and native world views.* Each of these paradigms reflects wisdom that addresses, at least in part, principles that have been relatively neglected by the other four planning theory traditions. To attempt

*An earlier version of this set was published previously in Roseland, M. (1997). Dimensions of the Eco-City. CITIES: The International Journal of Urban Policy and Planning 14(4), 197-202. 
such a broad survey in such a short space one must of necessity overgeneralize, but the view that emerges from this survey is worth that risk.

Healthy Communities: Public health has been among the traditional responsibilities of local government. A century ago, municipalities were instrumental in improving public health by preventing the spread of disease through slum clearance, community planning, water treatment, and the provision of certain health services. These early interventions were based on the view of health as the absence of disease, and disease prevention as the main challenge for local government.

In the last two decades a new, broader conception of public health has been developed and adopted by municipal governments in Europe and North America. Although the name "healthy communities" implies a focus on medical care, the Ottawa Charter for Health Promotion (WHO, 1986) recognizes that "the fundamental conditions and resources for health are peace, shelter, education, food, income, a stable eco-system, sustainable resources, social justice, and equity."

Local governments play a big role in all these areas through their impact on public hygiene (waste disposal and water systems), food handling and other public health regulations, recreational facilities, education, transportation, economic development, and land use planning. In Europe the World Health Organization has directed the successful creation of a 30-city network known as the Healthy Cities Project. In Canada, there have been approximately 100 active healthy community projects, and interest has been growing in Seattle and other US cities.

Appropriate Technology:* E.F. Schumacher in 1973 coined the term "intermediate technology" to signify "technology of production by the masses, making use of the best of modern knowledge and experience, conducive to decentralization, compatible with the laws of ecology, gentle in its use of scarce resources, and designed to serve the human person instead of making him [sic] the servant of machines" (Schumacher, 1973). The central tenet of appropriate technology (AT) is that a technology should be designed to fit into and be compatible with its local setting. Examples of current projects which are generally classified as AT include passive solar design; active solar collectors for heating and cooling; small windmills to provide electricity; roof-top gardens and hydroponic greenhouses; permaculture; and worker-managed craft industries. There is general agreement, however, that the main goal of the AT movement is to enhance the self-reliance of people on a local level. Characteristics of self-reliant communities which AT can help facilitate include: (1) low resource usage coupled with extensive recycling; (2) preference for renewable over nonrenewable resources; (3) emphasis on environmental harmony; (4) emphasis on small-scale industries; and (5) a high degree of social cohesion and sense of community (see e.g. Mollison, 1978, 1979; Olkowski et al., 1979; Darrow et al., 1981; RAIN, 1981). Communities that could be said to be practicing AT include the Amish of Lancaster County, Pennsylvania and the Menonites of southern Ontario (Foster, 1987).

Social Ecology: $\dagger$ Social ecology focuses its critique on domination and hierarchy per $s e$ : the struggle for the liberation of women, of workers, of blacks, of native peoples, of

*Also known as alternative, renewable, soft, intermediate, radical, liberatory, and human-scale technology. $\dagger$ Social ecology is a term with various meanings in various places, e.g. a branch of urban sociology. The social ecology referred to here, however, is focused primarily around the writings of Murray Bookchin. 
gays and lesbians, of nature (the ecology movement), are ultimately all part of the struggle against domination and hierarchy. Social ecology is the study of both human and natural ecosystems, and in particular the social relations that affect relationship of society as a whole with nature. Social ecology advances a holistic worldview, appropriate technology, reconstruction of damaged ecosystems, and creative human enterprise. It combines considerations of equity and social justice with energy efficiency and appropriate technology. Social ecology goes beyond environmentalism, insisting that the issue at hand for humanity is not simply protecting nature but rather creating an ecological society in harmony with nature. The primary social unit of a proposed ecological society is the eco-community, a human-scale, sustainable settlement based on ecological balance, community self-reliance, and participatory democracy.

Social ecology envisions a confederation of community assemblies, working together to foster meaningful communication, co-operation, and public service in the everyday practices of civic life, and a "municipalist" concept of citizenship cutting across class and economic barriers to address dangers such as global ecological breakdown or the threat of nuclear war. Co-operation and co-ordination within and between communities is considered able to transcend the destructive trends of centralized politics and state power. The city can function, social ecology asserts, as "an ecological and ethical arena for vibrant political culture and a highly committed citizenry" (Bookchin, 1987).

The Green Movement: The Greens believe in the "four pillars" of ecology, social responsibility, grassroots democracy, and nonviolence (Capra and Spretnak, 1984).* These pillars translate into principles of community self-reliance, improving the quality of life, harmony with nature, decentralization, and diversity. $\dagger$ From these principles, the Greens question many cherished assumptions about the rights of land ownership, the permanence of institutions, the meaning of progress, and the traditional patterns of authority within society. The Greens recognize that their movement will have to take different forms in different countries (Capra and Spretnak, 1984). Starting in the mid-1970s in New Zealand (where it was called the Values Party), France (Les Vertes), and West Germany (Die Grünen), the Green movement soon spread to many other developed countries in Europe and North America. In countries with proportional representation, such as Germany, Green politicans have been elected to seats in the Bundestag. Indeed, in 1998 the German Greens became the junior partner in the coalition federal government. In North America, however, Greens admit their involvement in federal political campaigns is primarily a way to educate the populace and build the movement. Local campaigns may be considered more serious bids for power, as when the Arcata, California Greens won a majority of seats on city council in 1996. Most North Americans still think Green simply means being pro-environment, but for Germans being Green means being feminist, supporting civil liberties, working for solidarity with Third World peoples, and standing for an end to the arms race (Swift, 1987).

Bioregionalism: The central idea of bioregionalism is place. Bioregionalism comes from bio, the Greek word for life, as in "biology" and "biography," and regio, Latin for

\footnotetext{
*Greens in the U.S. have generally expanded this list to include an explicit emphasis on decentralization (see e.g. Tokar, 1987).

$\dagger$ Tokar (1987) adds freedom, equality, and democracy to the list.
} 
territory to be ruled. Together they mean "a life-territory, a place defined by its life forms, its topography and its biota, rather than by human dictates; a region governed by nature, not legislature" (Sale, 1985). A bioregion is considered to be the right size for human-scale organization: often defined as a river basin or as a watershed, it is a natural framework for economic and political decentralization and self-determination. Bioregional practice is oriented toward resistance against the continuing destruction of natural systems, such as forests and rivers, and toward the renewal of natural systems based on a thorough knowledge of how natural systems work and the development of techniques appropriate to specific sites (Dodge, 1981).

While bioregionalism as a movement is relatively new, its precursors date back at least a century.* Like social ecology, it is rooted in classical anarchism. The implications of bioregional social organization are clearly for local political control by communities on their own behalf combined with broader allegiance to an institutional structure that governs according to an ecological ethic. Bioregionalism considers people as part of a life-place, as dependent on natural systems as are native plants or animals. By virtue of the emphasis it places on natural systems, perhaps, bioregionalism may perhaps appear weak in terms of human systems; however, some "Green City" ideas (e.g. Berg et al., 1989) are rooted in bioregionalism.

Recent volumes edited by bioregionalist Doug Aberley explain how to do bioregional mapping for local empowerment (1993) and cover the history and theory of ecologically sound planning (1994). The "ecological footprint" analysis developed by Wackernagel and Rees (1996) is a bioregional tool which can consider the impact of cities on natural resources and ecosystems. Their work demonstrates that although some industrial cities may appear to be sustainable, they "appropriate" carrying capacity not only from their own rural and resource regions but also from "distant elsewheres," i.e. they import sustainability.

Native world view: $\dagger$ Although the subject of considerable debate, many observers (see e.g. McNeeley and Pitt, 1985) argue that sustainable patterns of resource use and management have for centuries been reflected in the belief and behaviour systems of indigenous cultures. These systems traditionally have been based in a world view that does not separate humans from their environment (Callicott, 1982):

The Western tradition pictures nature as material, mechanical, and devoid of spirit..., while the American Indian tradition pictures nature throughout as an extended family or society of living, ensouled beings. The former picture invites unrestrained exploitation of non-human nature, while the latter provides the foundations for ethical restraint in relation to non-human nature.

The World Commission on Environment and Development recognized how much industrialized cultures have to learn about sustainability from traditional peoples, and at the same time, how vulnerable the latter are to encroachment by the former (WCED, 1987). As a Native Chief speaking at a symposium on sustainable development suggested,

* Elements of bioregionalism can be traced back to the writings of, for example, Kropotkin, Geddes, and Mumford.

$\dagger \mathrm{I}$ wish to thank Dr. Julia Gardner for this discussion of native world views. 
mainstream society would be wise to look at Native "history, culture, and traditions and practices, and find out how they managed to survive for thousands of years before European contact" (Smith, 1989).

\subsubsection{Comparing the planning paradigms}

Comparison of these alternative-planning paradigms with Friedmann's planning theory traditions reveals two overwhelming conclusions. First, the alternative planning paradigms are exceedingly rich in material relevant to sustainable development concerns, whereas Friedmann's four traditions of planning theory are relatively impoverished and uninspired in relation to sustainable development. Second, the alternative paradigms are particularly strong in the sustainable development areas where Friedmann's planning theory traditions are particularly weak: future equity, building capacity toward sustainability, maintaining environmental assets for future generations, and avoiding irreversible damage to any single significant environmental asset.

This finding has significant pedagogical implications for the education and training of professional planners and other municipal officials who increasingly must address sustainable development issues and concerns in their work. It indicates that much of what is currently taught in the name of planning theory is of limited value in addressing sustainable development, and that planners concerned with these aspects of sustainable development must look elsewhere for relevant theoretical guidance. This implies that planning theory educators should re-evaluate their syllabi to expose their students to this body of literature. As Rees (1992a,b) argues, sustainable development requires appropriate philosophy more than appropriate technology. 


\section{CHAPTER 4}

\section{Implications for achieving sustainable development in communities}

Much of the debate over the meaning of sustainable development focuses on the tension between the economic necessity for material growth and the ecological reality of limits. In the years since The Limits to Growth (Meadows et al., 1972) was published, few researchers have seriously explored the implications of this concept for social organization, work, and community economic development (e.g. see Meadows et al., 1992). Ryle (1988) notes that "ecological limits may limit political choices, but they do not determine them." The heart of the growth issue is simply that "underlying the social democratic advocacy of economic expansion is the fact that within a capitalist market framework, 'growth' is indeed the prerequisite of much else: especially, of the provision of welfare services and the creation of jobs, and of national economic status vis-á-vis other capitalist powers. Thus the critique of growth becomes a critique of capitalism and the market... an alternative would have to find new, non-market-based means of providing employment and of meeting welfare needs" [emphasis added].

Just as sustainability has prompted a shift in our transportation and energy planning away from the traditional concerns with increasing supply to the new focus on managing demand, we must also shift our economic development emphasis from the traditional concern with increasing growth to reducing social dependence on economic growth, or what we might call economic demand management (Roseland, 1998). This has distinct implications for sustainable community development, particularly regarding the future of work and community economic development.

\subsection{The future of work}

According to Statistics Canada, since the $40 \mathrm{~h}$ work week became standard in the $1960 \mathrm{~s}$ Canadian worker output per hour has more than doubled in many sectors. At the same time unemployment, overtime hours, and incidents of stress-related worker health problems have continued to rise (Karasek and Theorell, 1990).

Harvard economist Juliet Schor argues that many North Americans are working themselves to death. Since the end of the Second World War, for example, labour productivity in the US has almost tripled. Previously, workers gained leisure time as a result of increased productivity. In the postwar era, however, wage increases almost exclusively fuelled the increase in per capita consumption, which rose almost as much as productivity, rather than increasing free time. Consumption is an important motivator in modern society - that is, people work more to support a lifestyle in which material wealth is integral to happiness. The decline in "associational" activity observed by Putnam (1995) is tied in part to this time versus money tradeoff. Most North Americans spend most of their recreational time watching television and shopping. These changes in the way North Americans work and spend their time erode the extent and quality of community and of civil society (Schor, 1992). 
Much of the unrecognized work that maintains the social economy, ${ }^{*}$ which in turn is the foundation for the market economy, is performed by women. This includes reproductive work, household work, parenting, caring for the old and the sick, home-based production for use, and subsistence agriculture (Henderson, 1991, 1996; Schor, 1992; Lerner, 1994; Brandt, 1995; Korten, 1995).

Several proposals have been made for employment reform that helps manage economic demand and more fairly distributes work and leisure. Key elements of these proposals include shorter work weeks and improving part-time employment options. Implementation of such work alternatives brings forth a myriad of challenges including employee benefit reform and incentives for volunteer and community service work for which there is social demand but no market demand.

The emerging literature on the future of work (see e.g. Schor, 1991, 1992; O'Hara, 1993, 1994; Lerner, 1994; Rifkin, 1995) provides valuable insight into alternative work models and the sustainable development implications of employment. Much of this work, however, is highly theoretical and national or international in scope, ignoring community development implications and the challenges of implementing sustainable development at the community level.

Potentially significant employment opportunities, consistent with more sustainable patterns of development, exist in many economic sectors. Redesigned and improved infrastructure, knowledge-based services, environmental technologies, improved management and use of natural resources, and tourism are all rich areas for private sector investment, supportive government policies, and expanded training. Some of the most promising employment opportunities include (Shea, 1994):

- upgrading the efficiency of energy use in buildings, products, and transportation systems;

- adopting and implementing sustainable forestry, fisheries, soil, and watershed management practices;

- expanded delivery and use of information technologies;

- sustainable tourism activities centred around areas of environmental, cultural, and historic significance;

- recycling and remanufacturing of solid and hazardous waste into marketable products;

- accelerated and expanded development of marine and freshwater aquaculture;

- adding value to fish, agricultural, and forest products;

- developing, manufacturing, and marketing products, services, and technologies that reduce environmental burdens; and

- designing energy-efficient and people-friendly cities.

\footnotetext{
*The social economy consists of "mutual, co-operative relationships" which "create a dense fabric of relationships based on long-term sharing and co-operation." It maintains "the ethical structure, social stability, and personal security on which the smooth function of a market depends" - a fact which is routinely overlooked by economic policy makers. It is not, therefore, counted in national income statistics, does not contribute to measured economic growth, and is undervalued by policymakers who count only activities in the market economy as productive contributions to national output. The social economy is founded on values of co-operation, sharing, trust and mutual obligation. "Social economies are by nature local, non-waged, non-monetized, and nonmarket" (Korten, 1995).
} 


\subsection{Community economic development}

The concept of community economic development (CED) provides a means of addressing sustainable development at the community level. CED is also a constructive way to tap into the creative energies of the "sustainable people" described above that exist in most communities. A rapidly evolving field, the distinguishing features of community economic development are characterized by the following working definition (SFU CEDC, 1996):

Community Economic Development is a process by which communities can initiate and generate their own solutions to their common economic problems and thereby build long-term community capacity and foster the integration of economic, social and environmental objectives.*

Other observers describe CED in less flattering terms, arguing that in response to external funding priorities, community development organizations have lost their original focus on the creation of local employment opportunities and local control and generation of capital in low-income communities (Surpin and Bettridge, 1986). Examples of CED range from small business counselling and import substitution ("buy local") programs to worker co-operatives, community development corporations, and community land trusts. Boothroyd (1991) argues that "[w]hether CED is practised in hinterland resource towns, urban ghettos, obsolescent manufacturing cities, or Native communities' reserves, the general objective is the same: to take some measure of control of the local economy back from the markets and the state."

Achieving sustainable community economic development means emphasizing sustainable employment and economic demand management (EDM). Sustainable employment includes turning "wastes" into resources (e.g. recycling); improving efficiency with regard to energy and materials; converting to greater reliance on renewable energy sources; increasing community self-reliance (e.g. food and energy production); and sustainable management of natural resources (e.g. community forestry). EDM shifts our economic development emphasis from the traditional concern with increasing growth to instead reducing social dependence on economic growth.

Examples of sustainable community economic development include car co-operatives to reduce the cost and necessity of car ownership (Vancouver), sustainable employment plans to create jobs, spur private spending, and reduce pollution through public investment in energy conservation and audits (San Jose, California), new product development to encourage manufacturers to develop environmentally friendly products through municipal $\mathrm{R} \& \mathrm{D}$ assistance (Gothenberg, Sweden), increasing affordable housing supply through zoning codes that promote a variety of housing types, including smaller and multi-family homes (Portland, Oregon), experimenting with local self-reliance by establishing closedloop, self-sustaining economic networks (St. Paul, Minnesota), community supported agriculture to preserve farmland and help farmers, while making fresh fruits and

* This definition is based on the founding report for the Centre, written by David Ross and George McRobie in 1987. McRobie was a colleague of E.F. Schumacher. His Small Is Possible (1981) was inspired by Schumacher's Small Is Beautiful (1973). 
vegetables available in city neighbourhoods (Vancouver; London, Ontario; New York City), local currencies such as LETS: Local Employment and Trading Systems (Toronto), a local ownership development project with a revolving loan fund to encourage employeeowned businesses, considered more stable over the long term and more likely to hire, train and promote local residents (Burlington, Vermont), and a community beverage container recycling depot which employs street people - "dumpster divers" - and provides them with skills, training, and self-esteem (Vancouver).

\subsection{Directions for the future}

Four arguments inform this chapter. First, the term "sustainable development" acquires tangible meaning when understood in terms of natural capital and natural income. The bottom line for sustainability is that we must learn to live on our natural income rather than deplete our natural capital. Economic growth with an ecological deficit is anti-economic and makes us poorer rather than richer in the long term (Daly and Cobb, 1989).

Second, natural capital and social equity demand that North Americans, who are among the world's most inefficient and wasteful consumers of materials and energy (WCED, 1987), find ways of living more lightly on the planet. At a minimum, we will have to increase the efficiency of our resource and energy use. More likely, we will also have to reduce our present (not to speak of projected) levels of materials and energy consumption.

Third, reducing our materials and energy consumption need not diminish and, in fact, would likely enhance our quality of life and the public domain - in other words, our social capital. It is important to distinguish between "quality of life" and "standard of living" (Jacobs, 1993). "Standard of living" generally refers to disposable income for things we purchase individually, whereas "quality of life" can be considered as the sum of all things which people purchase collectively (e.g. the health care system, public education, policing), or those things which are not purchased at all (e.g. air quality). "Standard of living" refers solely to the private domain, whereas "quality of life" refers to the public domain, the realm of social capital.

Fourth, the critical resource for enhancing social capital is not money - rather, the critical resources are trust, imagination, the relations between individuals and groups, and time, the literal currency of life. Many of the social issues that people relate to most intimately - family, neighbourhood, community, decompression from work, recreation, culture, etc. - depend on these resources at least as much as money. This is not to say that economic security isn't important - it is - but focusing solely on money to provide security is using 19th century thinking to address 21 st century challenges.

Taken together, the direction to which these arguments point is clear. We must explicitly aim to nurture and multiply social capital in order not only to preserve our stock of natural capital but also to improve our economic and social well-being. Government and corporate decisions should be reviewed for their effects on both natural and social capital. Programs and policies need to be effected at every level to insure that natural and social capitals are considered properly. 


\section{CHAPTER 5}

\section{A framework for sustainable community development*}

This chapter builds upon the previous material to develop a framework for sustainable community development. It will add to the concepts of natural capital and social capital discussed in Chapter 2 to make them meaningful and relevant at the community level. The framework under discussion here is presented visually in Fig. 1.

What is a sustainable community? The concept of a "sustainable community" does not describe just one type of neighborhood, town, city or region. Activities that the environment can sustain and which the citizens want and can afford may be quite different from community to community. Rather than being a fixed thing, a sustainable community is continually adjusting to meet the social and economic needs of its residents while preserving the environment's ability to support it. Here is how some Minnesota citizens defined sustainable community (Minnesota SEDEPTF, 1995):

A sustainable community is "a community that uses its resources to meet current needs while ensuring that adequate resources are available for future generations. A sustainable community seeks a better quality of life for all its residents while maintaining nature's ability to function over time by minimizing waste, preventing pollution, promoting efficiency and developing local resources to revitalize the local economy. Decision-making in a sustainable community stems from a rich civic life and shared information among community members. A sustainable community resembles a living system in which human, natural and economic elements are interdependent and draw strength from each other."

This chapter develops a framework for sustainability at the community level. It begins with a look at communities in developed and developing parts of the world, proceeds to investigate some of the reasons why North American communities are presently unsustainable, explores some characteristics of more sustainable communities, and concludes with the role of citizens and their governments in moving toward sustainable communities.

\subsection{Sustainable communities north and south}

For the first time in history, nearly half of the world's people now live in urban areas areas characterized by human structures and activities. The way our communities develop will largely determine our success or failure in overcoming environmental challenges and achieving sustainable development. Cities and towns provide enormous, untapped opportunities to solve environmental challenges; they must and can pioneer new approaches to sustainable development and community management. As Harvey (1996) has observed, "The tangible recognition that the mass of humanity will be located in living environments designated as urban says that environmental politics must pay as much if not more

*This chapter is adapted from Roseland, M., 1998. Toward Sustainable Communities: Resources for Citizens and Their Governments. New Society Publishers, Gabriola Island, BC. 




Fig. 1. A framework for sustainable community development.

attention to the qualities of those built environments as it now typically does to a fictiously separated and imagined 'natural' environment." Local governments must also assume the responsibility and marshall the resources to address the sustainability problems facing their communities (Toronto Declaration on World Cities and Their Environment, 1991).

The communities of the developing (Southern) world face distinctly different challenges than those faced by the communities of the developed (Northern) world. From the perspective of sustainable development, the basic problem with Northern cities is that they are unsustainable, whereas the basic problem with Southern cities is that they are underdeveloped. Most Northern city-dwellers are adequately housed and fed, but they meet their needs by consuming at rates the planet cannot afford and polluting at rates the planet cannot tolerate. Many Southern city-dwellers cannot meet their basic needs for food, clean water, clean air, fuel, transport and an environment free of disease-causing agents. While this dichotomy is not absolute - i.e. there is poverty in most Northern cities, and many Southern cities live beyond their means in terms of consumption of natural resources such as firewood and water - it helps illuminate the essential challenge of urban sustainability both North and South: meeting basic needs without depleting or degrading natural capital (Holmberg et al., 1991).

The cities of the industrial world, with their inadequate urban policies and technology, set the standard to which city managers in low-income countries aspire - low density single family dwellings, cars, expressways, waste creation, air conditioning and profligate water use (White and Whitney, 1990). The role of the cities of the industrial world deserves much more scrutiny in the context of human settlements and the environmental crisis, precisely because their impact on the world's changing ecosystems is so enormous.

Approaches to accounting for the environment in urban economic development illustrate the differences between traditional environmental economics and a more ecological approach. Traditional environmental economics perceives environmental problems in terms of a deteriorating local environment, e.g. landfills approaching capacity from the growing waste stream. Solutions are cast in terms of finding efficient trade-offs 
between economic growth and environmental quality and finding policy instruments that will internalize the costs of pollution to those firms causing the problems. In contrast, the ecological ("strong sustainability") approach reveals new facets of the problem that are invisible to conventional economic policy models. Here attention is on the total relationship between the human population of the urban region, prevailing levels of ecologically significant consumption, and the sustainability of the resource base (Rees, 1992a,b).

\subsection{The unsustainable community}

Most North American cities were built using technologies which assumed that abundant and cheap energy and land would be available forever. Communities therefore grew inefficiently, and became dependent on lengthy distribution systems. Cheap energy influenced the construction of our spacious homes and buildings, fostered our addiction to the automobile, and increased the separation of our workplaces from our homes. As described by Calthorpe (1989):

The current round of suburban growth is generating a crisis of many dimensions: mounting traffic congestion, increasingly unaffordable housing, receding open space, and stressful social patterns. The truth is, we are using planning strategies that are forty years old and no longer relevant to today's culture. Our household makeup has changed dramatically, the work place and work force have been transformed, real wealth has shrunk, and serious environmental concerns have surfaced. But we are still building World War II suburbs as if families were large and had only one breadwinner, as if jobs were all downtown, as if land and energy were endless, and as if another lane on the freeway would end congestion.

Urban sprawl is one legacy of abundant fossil fuel and our perceived right to unrestricted use of the private car whatever the social costs and externalities. Other local and regional consequences of sprawl, such as congestion, air pollution, jobs-housing location "imbalance," and longer commuting times are now commonly recognized. Yet, until recently, few researchers acknowledged that the land use pattern of North American cities also has serious global ecological ramifications.

For example, residents of most Canadian cities annually produce about 20 tons of carbon dioxide per capita, placing Canada among the top three or four nations in terms of per capita contribution to potential climate change. In contrast, citizens of Amsterdam produce only 10 tons of carbon dioxide per capita per year. Sprawl, exclusionary zoning and low density, account for much of this difference. According to research at the International Institute for Applied Systems Analysis, if North American cities modelled future development on cities like Amsterdam, future carbon dioxide emissions here would only be half as much as current gloomy projections now indicate (Alcamo, 1990).

One way to consider the impact of a community on natural resources and eco-systems is to consider its "ecological footprint": the land area and the natural capital on which it draws to sustain its population and production structure (Wackernagel and Rees, 1996). Cities and towns demand a high input of resources - water, fossil fuels, land and all the goods and materials that their populations and enterprises require. The more populous the city and the richer its inhabitants, the larger its "ecological footprint" is likely to be in 
terms of its demand on resources and, in general, the larger the area from which these are drawn.

Although some of our cities may appear to be sustainable, analysis of the "ecological footprint" of industrial cities shows that they "appropriate" carrying capacity not only from their own rural and resource regions but also from "distant elsewheres" - in other words, they "import" sustainability. The flip side of importing sustainability is exporting ecological degradation, or unsustainability, since the production or extraction of natural resources in distant places often causes serious problems of environmental degradation there. Most North American cities (as well as those in Europe, Japan, Australia and other developed parts of the world) can only have forests, parks, and nature reserves nearby because such land is not being used to meet the demand for food and other natural resources which are instead imported.

The average North American's "footprint" has grown to measure 4-5 hectares, somewhat more than three city blocks, while the amount of ecologically productive land available has decreased this century from over five hectares to less than 1.5 hectares per person in 1994. Ecological footprint analysis shows that the residents of the Lower Fraser Valley (which includes the city of Vancouver, BC), with 1.8 million inhabitants and a population density of 4.5 people per hectare, depend on an area 19 times larger than that contained within its boundaries for food, forestry products, carbon dioxide assimilation and energy. The country of Holland, with 15 million people, or 4.4 per hectare, requires about 15 times the available land within their own country for food, forest products, and energy use, even though Dutch people consume less on average than North Americans (Wackernagel and Rees, 1996).

Ecological footprint analysis confirms our need to minimize consumption of essential natural capital. If everyone lived like today's North Americans, it would take at least two additional planet Earths to produce the resources, absorb the wastes, and otherwise maintain life-support.

\subsection{The sustainable community}

The postwar pattern of Western urban development is not only ecologically unconscionable but economically inefficient and socially inequitable. In contrast, sustainable development implies that the use of energy and materials be consistent with production by such "natural capital" processes as photosynthesis and waste assimilation (Rees, 1990a,b). To some authors this implies increasing community and regional self-reliance to reduce dependency on imports (RAIN, 1981; California Office of Appropriate Technology, 1981; Morris, 1982). The benefits would be reduced energy budgets, reduced material consumption, and a smaller, more compact urban pattern interspersed with productive areas to collect energy, grow crops, and recycle wastes (Van der Ryn and Calthorpe, 1986).

Movement toward sustainable communities requires a new kind of "ecosystem" thinking about human settlements. As described by Brugmann and Hersh (1991):

In this century, the city has been imagined by sociologists, planners, and engineers as a bazaar, a seat of political chaos, an infernal machine, a circuit, and, more hopefully, as a community, the human creation "par excellence." These different 
ways of thinking about cities, their social forces, their market behaviours, their reliance on materials and processes from the natural world, both shape and constrain the programmes and policies that local governments put forward to serve the needs of urban people.

The city can also be imagined as an ecosystem. Such a concept provides a tool to understand the complex relations between human activities and the environment, and how communities can organise their activities to both meet human needs and benefit the environment...

Like a natural system such as a pond or forest, an urban ecosystem transforms energy (human labour, capital, fossil fuels) and materials (timber, iron, sand \& gravel, information, etc.) into products that are consumed or exported, and into by-products. In natural systems by-products are recycled. We have designed and managed our cities so that these by-products often go unused as wastes. The impact of human activity on the environment can be highlighted by charting the dynamics of the system - the movement of materials and people, the flows of energy and capital, the locations where energy is stored or expended, the rates at which wastes are generated and recycled. By looking at the city as a whole, by analysing the pathways along which energy and pollution move, we can begin to see how human activities create and direct pollution into local, regional, and global ecosystems. We can also see how these activities can be reorganized and reintegrated with natural processes to increase the efficiency of resource use, the recycling of "wastes" as valuable materials, and the conservation of energy.

Australian researcher Peter Newman (1990) notes that "the most unsustainable form of settlement yet developed - the low density suburb - has been a relatively recent phenomenon, motivated by a strong anti-urban Anglo-Saxon sentiment and facilitated by the automobile. Social organization for ecological sustainability will need to reverse this settlement pattern." His analysis of settlement patterns and sustainability suggests that sustainable settlements require making cities more urban and making the countryside more rural.

Making cities more urban can be accomplished by "re-urbanizing" city centres and sub-centres; re-orienting transport infrastructure away from the automobile; removing subsidies on the automobile; and providing a more public-oriented urban culture, assisted by attractive urban design (townscapes, streetscapes, malls and squares) and by "traffic calming" measures to facilitate bicycle and pedestrian use of residential areas and major roads. Making the countryside more rural can be accomplished by means such as protecting and encouraging sustainable agriculture and forestry in rural areas and moving towards bioregionalism (e.g. air- and watershed management) as the basis of local government boundaries and responsibilities.

The ideal urban form for a particular locale will depend to some extent on the nature of the energy supply options: for example, higher densities make most efficient use of district heating and public transport networks, while lower densities may make solar energy more viable. The location, gross density and form of new development should therefore be 
determined in conjunction with programs for energy supply and conservation technologies (Owens, 1990). This principle is illustrated by a San Jose, California study which compared development pressures with or without a "greenbelt" to constrain development. Without it, 13000 exurban homes would be developed which, compared to an equivalent number of units downtown and along the transit corridor, would require at least an additional 200000 miles of auto commuting plus an additional three million gallons of water every day, as well as 40\% more energy for heating and cooling (Yesney, 1990).

Another study, by Montgomery County, Maryland, found that continued growth in an automobile-dependent pattern would produce traffic congestion levels high enough to choke off economic development. However, an anticipated doubling of population and employment could be accommodated without excessive traffic problems if most new growth were clustered in pedestrian- and bicycle-friendly centres focused on an expanded rail transit and busway system. Through such strategies, the share of County work trips made by non-auto alternatives could double to $50 \%$, resulting in only half the level of energy use and air pollution compared to the sprawled, automobile strategy (Replogle, 1990).

As these examples demonstrate, the pattern of growth is more important than the amount of growth in determining the level and efficiency of resource use and traffic congestion. They also show that a critical sustainability objective for our communities is more efficient use of urban space. This objective, as we will see throughout this article, is very compatible with the objectives discussed in the previous chapter, minimizing consumption of natural capital, and multiplying social capital.

\subsection{Mobilizing citizens and their governments}

There is no (and perhaps should not be any) single accepted definition of "sustainable communities." Communities must be involved in defining sustainability from a local perspective. The dilemma is how to encourage democracy (e.g. participatory local processes) within a framework of sustainability. As we have seen, elements of this framework include minimizing consumption of essential natural capital, multiplying social capital, and more efficient use of urban space. However, a fourth element is required to co-ordinate and balance the other three.

There are legitimate causes for concern about the dislocations, economic costs, and potential inconveniences associated with sustainability measures and their distribution across society. Both the gain and the pain of adjustment should be shared fairly by community members. Participation in the decision process by affected groups "can help make the attendant redistribution of costs and benefits fairer and more widely understood. Democratic mobilization is essential to the achievement of such policies in the face of the opposition [by vested interests they] inevitably engender" (Paehlke and Torgerson, 1990).

Environmental organizations and activists, especially in the United States and Canada, have tended to focus narrowly on specific campaigns of one kind or another, and may find it difficult to see how their work fits into the larger social, political and economic context. Yet the current popularity of the term "sustainable development" requires those concerned with environmental protection to cooperate with others in meshing environmental 
critiques, goals and strategies with those of peace, social justice, equality and economy, etc. (Gibson, 1991; PCSD, 1996).

In general, sustainable development strategies should favour bottom-up over top-down approaches; redistribution over "trickle-down;" self-reliance over dependency; a local rather than a regional, national, or international focus; and small-scale projects rather than grand-scale or megaprojects. As well, they should be designed with extensive public participation; seek to improve society and the environment as well as the economy; and result in increased equity, equality and empowerment (Brohman, 1996).

Democracy is an inherent part of the sustainable development process. Sustainable development must be participatory development. For people to prosper anywhere they must participate as competent citizens in the decisions and processes that affect their lives (Gran, 1987). Sustainable development is thus about the quantity and quality of empowerment and participation of people. Sustainable development therefore requires mobilizing citizens and their governments toward sustainable communities.

\subsection{A framework for sustainable community development}

In summary, applying the concept of sustainable development to North American communities begins with unprecedented and simultaneous emphasis on the efficient use of urban space, on minimizing the consumption of essential natural capital, on multiplying social capital, and on mobilizing citizens and their governments toward these ends. This last element is crucial to co-ordinating and balancing the other three (see Fig. 1). 


\section{CHAPTER 6}

\section{Governance for sustainable community development}

With our framework for sustainable community development in hand, we turn our attention now to governance for sustainable community development.

Governance and government are not the same. Government is about "doing" things, and delivering services, whereas governance is "leading" society, convincing its various interest groups to embrace common goals and strategies (Osborne and Gaebler, 1993).

This chapter is about governing sustainable communities, and explores both governance and government in this context. In particular, it focuses on public participation, decisionmaking, the role of local government, and planning for action.

\subsection{Public participation}

In the last several years there has been an enormous shift toward the "politics of inclusion." These new politics are here to stay, not only because they are demanded, but also because they ensure results that better fulfil the broad public interest than decisions that are shaped by the lobbying of powerful and vocal interests. For some categories of decisions that affect a broad spectrum of interests, a fair hearing is no longer sufficient to achieve a lasting and equitable result. Direct participation in the decisionmaking process is necessary (Owens, 1990).

The traditional approach to public demand for greater participation has been described as "decide, educate, announce, defend," otherwise known as DEAD. Collaborative processes are an alternative which can lead to better communication and understanding. Quite different perspectives can find common ground and agree to recommendations regarding particularly difficult issues. This does not necessarily mean that everyone comes to full agreement, but rather that there is no substantial disagreement; participants can live with the outcome.

Democratic decision-making, where decision-making power is shared in reality if not in name, has been effective in some contexts and some regions. Community development corporations in the Maritimes, community land trusts in the United States, and the Mondragon system of industrial co-operatives in the Basque region of Spain are all examples of the potential of democratic decision-making.

\subsubsection{Shared decision-making}

The primary rationale for enhanced stakeholder participation in community planning and governance is based on the democratic maxim that those affected by a decision should participate directly in the decision-making process. Within the broader framework of representative democracy, participatory democracy provides a system of checks and balances against the limitations of a purely representative system (Duffy et al., 1996).

The benefits of participative democratic structures have far-reaching implications for community planning. So-called "consultation" of stakeholders is no longer adequate (Arnstein, 1969; Marshall and Roberts, 1997). Stakeholders often demand genuinely 
co-operative decision-making, if not outright control over decision-making. In response, formal recognition has been provided at some levels of government through legislation legitimizing public participation initiatives. However, policy statements supporting stakeholder participation are inadequate if sufficient resources, staff, and commitment to implement meaningful participation do not back them. Truly meaningful participation requires that all concerned and affected stakeholders are provided the information and resources they require to influence and contribute to the decision-making process, and that planning and decision-making processes must be designed and implemented to foster comprehensive stakeholder participation. The issues of who participates, when they participate and how they participate are critical to achieving fairness, efficiency and stability in decisionmaking.

The essential difference between conventional and collaborative, or "shared decisionmaking" lies in the level of true collaboration and involvement of those not traditionally involved in decision-making (Crowfoot and Wondolleck, 1990). Specifically, shared decision-making involves planning with stakeholders rather than for stakeholders. Shared decision-making processes depend on the explicit recognition that all stakeholder values and interests are legitimate.

\subsubsection{Consensus decision making and its advantages}

Consensus is a process for making group decisions without voting. Agreement is reached through a process of gathering information and viewpoints, discussion, persuasion, a combination of synthesis of proposals and/or the development of totally new ones. Consensus does not necessarily mean unaminity. Rather, the goal of the consensus process is to reach a decision with which everyone can agree. Consensus at its best relies upon persuasion rather than pressure for reaching group unity.

The consensus method is most useful for groups whose members value their association highly. Consensus decision-making sometimes requires a great deal of patience. It is necessary to listen carefully to oposing viewpoints to reach the best decision. In spite of this drawback, the consensus method has the following advantages over a voting method (Coover et al., 1977): it produces more intelligent decisions, by incorporating the best thinking of everyone; it keeps people from getting into adversary attitudes where individual egos are tied to a proposal that will win or lose; it increases the likelihood of new and better ideas being thought up; everyone has a stake in implementing a decision, because all have participated in its formation (participants have more energy for working in groups with which they are fully in agreement); and it lessens significantly the possibility that a minority will feel that an unacceptable decision has been imposed on them.

Canada's National Round Table on the Environment and the Economy, in conjunciton with several provincial and local Round Tables, has articulated some of the guiding principles that characterize consensus processes. Consensus decision-making is (NRTEE, 1993):

Purpose Driven: People need a reason to participate in the process.

Inclusive: All parties with a significant interest in the issue should be involved in the consensus process. 
Voluntary: The parties who are affected or interested participate voluntarily.

Self-Designed: The parties design the consensus process.

Flexible: Flexibility should be designed into the process.

Fair: All parties must have equal access to relevant information and the opportunity to participate effectively throughout the process.

Respectful of Diverse Interests: Acceptance of the diverse values, interests, and knowledge of the parties involved in the consensus process is essential.

Accountable: The parties are accountable both to their constituencies and to the process that they have agreed to establish.

Time Limited: Realistic deadlines are necessary throughout the process.

Implemented: Commitment to implementation and effective monitoring are essential parts of any agreement.

\subsubsection{Alternative dispute resolution $(A D R)$}

Consensus is also used in the context of conflict management. Alternative dispute resolution (ADR) is a form of shared decision-making. Two key ADR strategies are negotiation and mediation. These processes are "alternative" in the sense that they are outside the conventional judicial, litigative route of problem-solving. Conventional legal channels are often criticized for being excessively costly and slow in resolving disputes (and therefore favouring those with time and money), for contributing to a climate of uncertainty in decision-making, and for emphasizing win/lose over win/win solutions. In response, interest in ADR has grown significantly.

Interest in consensus-based dispute resolution strategies is also increasing. In the context of dispute resolution, consensus generally refers to a situation in which all parties agree to a decision. This outcome may have been arrived at by one party being persuaded by arguments of another, or by both parties finding a new common goal (Minnery, 1985). Reaching a consensus may involve bargaining, negotiation, consultation, facilitation, factfinding and/or mediation in order to resolve conflicts. In contrast to a decision resulting from a vote or made unilaterally by a decision-making authority, a consensus process is qualitatively different in that each participant has an effective veto. This veto "levels the playing field" and provides each stakeholder with equal authority in reaching the decision. The power of consensus as a dispute resolution tool lies in its ability to protect the minority or single party from the "tyranny of the majority" (Cormick, 1989).

\subsection{Democracy and sustainability}

All of us play many roles in our society, such as worker, employer, parent, child, consumer, student, teacher, and so on, and all of these roles are important for moving toward sustainable communities. However, it is primarily in our role as citizens (and to a lesser extent, as consumers) that we can create sustainable communities and a sustainable economy. It is through participating in the governance of our communities that we can take the necessary measures to create a sustainable society. Sustainability will be adopted through active pressure on governments (for example, from citizen organizations and voluntary environmental groups) and through the power of the electoral system. Individual 
actions and lifestyle choices, such as recycling or bicycle commuting, are important personal contributions, but sustainability requires a collective shift in individual actions and political choices, which governments can only gain the authority to call for if people have voted for sustainability (Jacobs, 1993). Democracy is fundamental to sustainability.

Local government provides one of the best ways to demonstrate the necessity, the desirability, and the practicality of moving toward sustainable communities. Although local governments are not necessarily the only agencies charged with community planning and development, since they were elected locally, they are representative and accountable bodies responsible for community decision-making. This makes them critical players in the movement toward sustainable communities.

In the words of Peterborough, Ontario Mayor Sylvia Sutherland (1991):

We in local government are closest to our communities. We are closest to the people who must participate in a very direct and active way if the transition to sustainability is to have any hope of success. We are uniquely situated to assist in the evolution of new social values and practices. We can encourage co-operation between the sectors of the community with a stake in the environment and in development and sustainability. We can act as a catalyst for local action beyond the boundaries of our own jurisdiction...

Local governments are also important actors in their local economies. They build and maintain infrastructure that is essential for economic activity, and they set standards, regulations, taxes, and fees that determine the parameters for economic development. Local governments procure large numbers of services and products and can influence markets for goods and services. Like private enterprises, local governments serve as public enterprises to produce "products" that are sold on the market. These products include environmental services (e.g. water, waste management, and land use control), economic services (e.g. transportation infrastructure), and social services (e.g. health and education) (ICLEI, 1996).

Burlington et al. (1992) notes that sustainable development "requires that communities protect and enhance the environment upon which their future depends by changing the way they make decisions and by developing an ecological framework for planning sustainable communities. Translating the concept of sustainable development into action at the municipal level will require far-reaching institutional changes, changes in thinking, decision making, policy and process."

There are a variety of ways that local governments can respond to sustainable development and global environmental concerns. For example, Gilbert et al. (1996) has characterized eight styles of local government response with respect to potential climate change and global warming (see Table 2).

Local governments also operate under the considerable constraints of most public agencies: limited resources, jurisdiction, imagination, courage, time, and so on. For local governments to fulfil their potential in moving toward sustainable communities, they need citizen organizations as community partners.

Citizen organizations provide many innovative programs and concepts, and furnish whole new paradigms for problem definition, because they are able to tap and organize information laterally. They can network across borders as well as across corporate and government boundaries, enabling rapid syntheses of overlooked and new information into 
Table 2

Local government styles of response with respect to global warming (Gilbert, 1991)

\begin{tabular}{|c|c|c|}
\hline & Style & Examples \\
\hline 1. & Flout the law. & ...Use illegally polluting vehicles. \\
\hline 2. & Merely obey the law. & Do no more, or less, than is required. \\
\hline 3. & Set a good example within the administration. & Intra-office recycling; use natural gas vehicles. \\
\hline 4. & Advocate within jurisdiction. & $\begin{array}{l}\text { Encourage reduction, reuse, and recycling; promote } \\
\text { transit and district heating }\end{array}$ \\
\hline 5. & Legislate within jurisdiction. & $\begin{array}{l}\text { Ban certain materials at landfill sites; local } \\
\text { restrictions on automobile use. }\end{array}$ \\
\hline 6. & Advocate outside jurisdiction. & $\begin{array}{l}\text { Push for tighter automobile pollution standards; } \\
\text { promote inter-city rail. }\end{array}$ \\
\hline 7. & Seek new legislative authority. & $\begin{array}{l}\text { To tax automobile ownership; to ban sale of items } \\
\text { made with CFCs. }\end{array}$ \\
\hline 8. & Legislate outside jurisdiction. & $\begin{array}{l}\text { Ban sale of items made with CFCs; ban use of many } \\
\text { kinds of packaging. }\end{array}$ \\
\hline
\end{tabular}

fresh approaches and paradigms. Today, the most creative, energetic forces addressing the planetary problems of poverty, social inequity, pollution, resource depletion, violence, and war are grassroots citizens' movements. Hazel Henderson calls this "grassroots globalism" - pragmatic, local solutions that keep the planet in mind. These approaches "bubble up" rather than "trickle down," and they are often innovative, stressing positive action and role models (Henderson, 1996).

A good example of grassroots globalism is the overwhelming interest and participation of all kinds of organizations in the UN global conferences organized in the 1990s. This is not accidental, but rather the "tip of the iceberg" in a wide social process affecting all the continents: the emergence of organized civil society (ICPQL, 1996).

Civil-society groups vary in the causes they stand for and in their goals. Some are structured, capable of action with a sense of continuity; others are more "prophetic" in nature, likely to act intensively in a more episodic way. Still others endure changes from outside or within, intervening with forms of action that are permanent or else change during the entity's lifetime. Once empowered, citizens are quite capable of turning to those forms of organized action allowing them to apply pressure where they themselves are affected. The multiplicity of these forms of action, their cross-fertilization and their potential for confrontation create an enormous vitality within the social fabric (ICPQL, 1996).

\subsubsection{Leadership by example}

Local government is an influential employer and consumer in most communities. A key step toward making our communities sustainable is leadership by example, particularly "greening" City Hall. We need to insist that our local officials lead by example. As described throughout this article, a variety of tools are available for this purpose. Every community member has a legitimate interest in knowing what measures their local government is, could, or should be taking to make their community more sustainable.

Unfortunately, energy-efficient light bulbs and reusable china in the City Hall cafeteria will not in themselves achieve sustainable development or slow global climate change. 
These kind of well-intentioned initiatives are but small steps toward creating sustainable communities.

\subsubsection{Environmental administration}

Another key step toward sustainable communities is conceptual and organizational. One of the greatest obstacles to sustainability is the reductionist administrative mindset that subdivides problems and prevents the left hand of government from understanding what the right hand is doing. For example, despite considerable trumpeting of environmental protection programs (which are sometimes themselves endangered species), most sober analyses of public budgets and spending estimates conclude that governments spend billions of dollars more on programs and policies that create pollution and encourage environmental degradation (e.g. see RFI, 1991). Such bureaucratic schizophrenia is perpetrated at all levels of government as well as throughout academia.

Sustainable communities cannot be achieved through the kind of fragmented and bureaucratized administration that characterizes senior government. At the community level the issues of, for example, transportation, land use, economic development, public health, environmental protection, and housing affordability cannot be successfully managed as separate problems by separate agencies using separate strategies.

Conventional wisdom considers the environment as an administrative problem, to be solved by better management - understood as cutting the environment into bite-size pieces. This approach seems increasingly unable to deal effectively, sensitively, and comprehensively with environmental complexities.

Rather than the environment as an administrative problem, it would appear that administration is itself an environmental problem. One alternative to conventional municipal administration is an emerging form of what has been called "environmental administration." It can be characterized as non-compartmentalized, open, decentralized, anti-technocratic, and flexible (Paehlke and Torgerson, 1990). Environmental administration provides a holistic way of addressing both "environmental" issues and a whole range of community issues. Some examples of this approach are discussed below.

It will take a great effort over a long time to turn the system of local government into a paragon of environmental administration, though try we must. In these transition decades, however, an effective and popular way to implement sustainable community development is urgently required.

\subsubsection{Beyond local government}

A third key step toward sustainable communities is improving the context for sustainable community planning and governance. This requires looking beyond the local level toward regional, state/provincial, and federal policies and programs. These programs encourage, enable, and empower those communities which have already started to plan local initiatives for a sustainable future, and require the rest to begin.

\subsection{Sustainable community planning}

Sustainable community planning works best in the context of a supportive regional, provincial or state planning framework. The key is goal-oriented planning - that is, 
planning for sustainable community development. Governance systems in some regions have been relatively successful in planning and managing for a healthy environment.

Supportive national planning programs exist in France, Norway, Finland, and Holland. In North America, provincial or state legislation can require each town's land use to be compatible with specified regional interests, but leave the actual planning process up to the local community. In Canada, British Columbia passed Growth Strategies legislation in the mid-1990s. In the US, such legislation has given new force to urban planning in eight states: Florida, Georgia, Maine, Massachusetts, New Jersey, Oregon, Rhode Island, and Vermont. All cities and counties in these states are required to plan their own development according to stipulated goals, such as energy conservation, protection of open space, and provision of affordable housing. These statewide planning requirements not only enhance regional co-operation, but they also give cities the backing they need to apply a comprehensive, long-term vision to their land use planning (Lowe, 1992).

\subsubsection{Example initiatives}

Citizen organizations and local governments all over North America are engaging in sustainable community planning processes. Some notable initiatives are those of Chattanooga and the San Francisco Bay Area in the US, Ottawa, Hamilton-Wentworth, and Greater Toronto in Canada, and Curitiba in Brazil.

In 1969, Chattanooga, Tennessee was the worst polluted city in the US. In 1990 it was recognized as the country's best turn-around story. How did it happen? In 1984, the entire community was invited to envision what they wanted their community to be like by the year 2000. The shared vision of sustainable community development that emerged put affordable housing, public education, transportation alternatives, better urban design, parks and greenways and neighborhood vitality at the top of the community's agenda. Energetic collaboration of government agencies, manufacturers and citizens resulted in successful initiatives to clean up the air and revitalize a city in decline. Several ecoindustrial parks were established to rebuild the city's economic base, proving that economic development and environmental stewardship can be achieved together. Most importantly, all participants determined to set in motion a comprehensive, interrelated and strategic process for sustainable community development (Gilbert et al., 1996).

Urban Ecology organized a five-year participatory process to develop their Blueprint for A Sustainable Bay Area. It is based on providing residents with new choices for a prosperous life; protecting, restoring and integrating nature into people's lives; working toward social, economic and environmental justice; promoting development and transportation alternatives that connect the region; encouraging resource conservation and reuse; designing with respect for local and historical uniqueness; and enabling residents to nurture a strong sense of place, community and responsibility (Urban Ecology, 1996). The report's 95 recommendations reflect a range of tools and initiatives.

The Health, Family and Environment Committee of the San Francisco Board of Supervisors, with the support of the Mayor, in 1997 unanimously endorsed a Sustainability Plan that would guide decisions of all city commissions and departments. Air quality, solid waste, biodiversity, and food and agriculture are among the 10 major topics of the 150 -page plan. The plan's transportation suggestions include creating 10 auto-free zones over the next four years, increasing the city parking tax, raising gasoline taxes and bridge 
tolls, and introducing "congestion pricing" charges for driving at rush hour. Critics such as right-wing radio talk-show host Rush Limbaugh and the conservative magazine National Review have called it "eco-totalitarianism." San Francisco joins Santa Monica, California and Chattanooga as American cities with extensive environmental plans (GreenClips 76, 1997; Langton, 1997).

The City of Ottawa's 1992 Official Plan, developed through an elaborate public consultation process with solid community support, is based on the concept of sustainable urban development. The City's commitment to sustainable development is manifested in the Mission Statement, Guiding Principles, and the Vision for Ottawa found at the beginning of the Plan. Specific policies contained in the Plan are designed to reflect this commitment. For example, the housing policies promote affordable housing, infilling and intensification, which reflect the guiding principles of adequate shelter, and conservation and enhancement of the resource base. The transportation policies encourage increased use of public transportation, cycling, and walking, which reflect the guiding principle of increasing non-automobile transportation. In addition, the plan outlines the City's environmental impact assessment process, which is designed to address the cumulative impact of everyday practices and development projects on the environment (ORTEE, 1995).

The Sustainable Community Initiative is an ongoing collaborative process in which the Hamilton-Wentworth regional government, $75 \mathrm{~km}$ west of Toronto, has been working with thousands of citizens to turn a jointly-developed community vision into a reality. Since Vision 2020 was formally adopted in 1993, the regional government has devised an implementation strategy outlining the major policy shifts needed to achieve the vision, along with over 400 recommendations for specific action and a unique approach for monitoring progress - 28 sustainability indicators are compiled into an Annual Report Card, which is the basis of an Annual Sustainable Community Day and forum to assess progress in relation to the goals of Vision 2020. The Sustainable Community Initiative has already had a profound impact on the way the local government operates and is leading toward significant improvements to the local environment, including development of a bicycle commuter network, creation of habitat corridors for wildlife protection, and a home-energy and waste-auditing program (ICLEI, 1995).

In 1988 a Royal Commission on the Future of the Toronto Waterfront was created to examine matters related to "the use, enjoyment and development" of the area. By the mideighties the Toronto waterfront had become an embarrassment. Pollution had closed the beaches; expressways and condominium towers blocked public access, contaminated and abandoned industrial lands degraded the harbour area, and rehabilitation efforts were frustrated by jurisdictional squabbling among federal, provincial, regional and municipal authorities. The Commission, headed by former Toronto Mayor David Crombie, initiated broad public discussion of waterfront issues and quickly saw that the conventional, fragmented, waterfront-specific approach would not work, so they expanded its scope from the waterfront to the watershed. This larger area, which the Commission called the Greater Toronto bioregion, is home to four million people as well as innumerable other creatures in complex social as well as ecological relations. Before the Crombie Commission, the notion of bioregional or ecosystem planning was little known outside professional and citizen planning circles and did not seem likely to play a major role in 
guiding practical efforts to reunite economy, community and ecology. Now it is a real possibility that has begun to be tested in practice (Gibson et al., 1997).

Curitiba, Brazil has received international acclaim as a city that works for its integrated transportation and land use planing, and for its waste management programs. Both are good examples of sustainable community planning. But how did Curitiba manage to become a positive example for cities in both developed and developing countries? In part, the city's success can be attributed to strong leadership - city officials focused on developing simple, flexible and affordable solutions that could be realized at the local level and adapted to changing conditions. In addition, "the government promoted a strong sense of public participation. Officials were encouraged to look at problems, talk to the people, discuss the main issues, and only then reach for the pen" (Rabinovitch, 1996).

Cities are now banding together under the auspices of various regional associations and partnerships concerning approaches and solutions to common urban problems. The $\mathrm{CO}_{2}$ Reduction Program is a partnership co-ordinated by the International Council for Local Environmental Initiatives (ICLEI). More than 100 local governments from 27 countries have joined an International Cities for Climate Protection Campaign. Participants pledge to meet and exceed the requirements of the Framework Convention on Climate Change by reducing carbon dioxide emissions by up to $20 \%$ by 2005 . As part of this initative, ICLEI worked with 14 cities to develop comprehensive local action plans to reduce carbon dioxide emissions (Brugmann, 1996).

Jonas Rabinovitch, a long-time advisor to Curitiba Mayor Jaime Lerner, believes the lesson to be learned from Curitiba is that creativity can subsititute for financial resources. Any city, rich or poor, can draw on the skills of its residents to tackle urban environmental problems (Rabinovitch, 1996). All these examples confirm the importance, as discussed earlier, of multiplying social capital as a key to moving toward sustainable communities. 


\section{CHAPTER 7}

\section{Policy instruments and planning tools}

There are many ways to mobilize citizens and their governments toward sustainable communities, but there are also many barriers and obstacles that hamper our progress in this direction. We cannot realistically expect most people to choose sustainable options if they appear to be more difficult or expensive than unsustainable choices. The question arises, then, how can we change the systems around us, "level the playing field," and provide ample opportunities for individuals to make behavioural choices that improve their communities?

In recent years there has been increasing interest in the use of "economic instruments" in environmental policy. These tools influence the behaviour of economic agents by providing financial incentives to environmentally improved behaviour, or disincentives to damaging behaviour. Such instruments - taxes, charges, subsidies, tradable permits, deposit-refund schemes, performance bonds and so on - have been particularly favoured within the discipline of environmental economics, where they originated. As the influence of environmental economics has grown, so the calls to introduce economic instruments in fields such as pollution control and energy consumption have grown louder (Roseland and Jacobs, 1995).

Economic instruments should not be seen in isolation. When introduced they are inevitably part of a structure and process of community management which in turn reflect wider objectives - environmental, economic, social and ethical - in society.

For communities to move effectively toward sustainability, citizens and their governments should understand the range of policy instruments available to them and the wider context of how community policy is made. This chapter explores the use of policy instruments in sustainable community planning and development, and reviews the different types of instruments that are available to community decision-makers.

\subsection{Policy issues for local governments: a context for policy instruments}

Although there may always be debate over the precise characteristics of sustainable communities, there are characteristic objectives of local activity toward sustainable development which can be applied virtually anywhere. Several sustainability issues can be identified as important for local governments. These include infrastructure that results in environmentally respectful use of resources; minimization of waste and proper management of residues; energy-efficient transportation; compact land-use patterns; integrated transportation and land-use planning; local environmental assessments and audits; cooperation with non-governmental organizations in the implementation of environmental programmes; reducing economic and social polarization; and integration of marginalized people into efforts towards sustainable development (Gilbert et al., 1996).

Given these general concerns for local governments, some broad policy goals might include the following: reducing per capita car use; reducing per capita water consumption; increasing the percentage of local land contained in parks; improving cycling and 
Table 3

Policy instruments

\begin{tabular}{|c|c|c|}
\hline & Categories & Instruments \\
\hline A. & Regulations & $\begin{array}{l}\text { 1. Laws } \\
\text { 2. Licenses, Permits, and Standards } \\
\text { 3. Tradeable Permits } \\
\text { 4. Quid Pro Quos }\end{array}$ \\
\hline B. & Voluntary Instruments & $\begin{array}{l}\text { 1. Information } \\
\text { 2. Volunteers, Volunteer Associations, and Non-Governmental } \\
\text { Organizations } \\
\text { 3. Technical Assistance }\end{array}$ \\
\hline C. & Expenditure & $\begin{array}{l}\text { 1. Expenditure and Contracting } \\
\text { 2. Monitoring } \\
\text { 3. Investment and Procurement } \\
\text { 4. Enterprise } \\
\text { 5. Public-Private Partnerships }\end{array}$ \\
\hline D. & Financial Incentives & $\begin{array}{l}\text { 1. Pricing } \\
\text { 2. Taxes and Charges } \\
\text { 3. Subsidies and Tax Incentives } \\
\text { 4. Grants and Loans } \\
\text { 5. Rebates, Rewards and Surety Bonds } \\
\text { 6. Vouchers }\end{array}$ \\
\hline
\end{tabular}

pedestrian infrastructure, etc. Policy instruments can be employed to achieve these specific policy objectives.

\subsection{Policy instruments}

Two target populations for policy instruments can be identified, the general public and individual firms or industries. The use of instruments to influence the behavior of the public can be called demand management. One of the most important requirements for sustainability is a reduction in the per capita consumption of resources as communities grow (Wackernagel and Rees, 1996). Since supply of resources can only be augmented to a certain point, this inherently requires that demand for resources be managed. Instruments that try to influence the behavior of firms and industries are not usually considered to be demand management, but they serve the same purpose - to reduce the consumption of natural resources. In considering particular instruments, it is important to note what the target population of each would be.

In Table 3 the instruments are divided into broad categories, according to Jacobs (1993), although many instruments could actually fall into more than one category. The various policy instruments can be slotted into four categories. The first is traditional regulationssuch as permits and licenses that have a legal basis. A second category is voluntary mechanisms or actions taken that generally do not require expenditure. Third comes direct government expenditure such as money spent on improved infrastructure. Lastly, there are financial incentives such as taxes, subsidies, tradable permits, and rewards. Financial incentives do not require people to change their behavior or values, and do not usually require as much enforcement as regulations. 


\subsubsection{Constraints on implementation}

As noted previously, many policy instruments could fall into more than one category. In some cases there might be an overlap between regulations and financial incentives; it is also possible to have elements of two or more categories (e.g. expenditures and voluntary instruments) in the same policy measures. The critical challenge, however, is not in sorting the instruments by category but rather in determining those situations and circumstances in which it is appropriate to employ particular instruments.

An additional challenge is determining the efficacy of various instruments over longer time frames than are yet known for most of the examples discussed here. Organizations such as the International Council for Local Environmental Initiatives, as well as various local government associations in several countries, can serve a valuable role in monitoring and evaluating progress over time.

Although it is beyond the scope of this chapter to examine whether or not each of the instruments could be utilized in specific circumstances at the local level, some general considerations can be made. In many situations, some of the instruments may perhaps be best used only at a federal or state/provincial level, while others may be best used by local governments. In cases where jurisdictional limitations prevent local governments from taking essential actions, state/provincial governments can be lobbied to use their jurisdictional power to carry out initiatives that will benefit multiple communities.

The "principle of subsidiarity" maintains that policy-making should occur at the lowest or most local level possible while maintaining effectiveness (Osborne and Gaebler, 1993). Community planners should not simply copy the policy objectives of neighboring communities (Alexander, 1991), but instead realize that each community has its own unique environmental, economic, social, historical and cultural circumstances.

Local governments in recent years have been particularly innovative in initiating sustainability policies (ICLEI, 1996; Roseland, 1997, 1998; Local Environment [various issues]). In the US, although there is some power at the local level to take actions to pursue local objectives, some local planning initiatives have been viewed by the courts as inconsistent with state policies (Stone and Freilich, 1991). Local governments in Canada can also expect to be constrained by jurisdiction. Some analysts argue that the division of powers in Canada does not delegate enough power to communities, and prevents them from looking after their own affairs (M'Gonigle, 1991). Still, an instrument that is not feasible in one set of circumstances may work in another, so local policy-makers should consider all alternatives.

A system of government that does not give adequate legal power to local governments, and does not allow local governments considerable flexibility in the use of funds, cannot be expected to achieve all community objectives (Osborne and Gaebler, 1993). Central governments must give local governments permission to take measures towards sustainable community planning, even though that requires giving them power to address broader issues. At the same time, when issues that should be addressed at national and international levels are not addressed, local governments may be able to take action individually. For example, the cities of Irvine, California and Newark, New Jersey passed comprehensive bans on ozone-depleting compounds in 1989-90 when international agreements would have allowed their use for another decade. Community leadership helped ensure that atmospheric change was put high on the agenda of senior governments. 
It is interesting to speculate on the efficacy of economic instruments viz-a-viz other kinds of policy instruments in promoting sustainable community development. However, given the general reluctance (and perhaps inability) of governments at all levels today to consider non-economic and, particularly, non-market policy instruments, it is wise as well as timely to improve our understanding of economic policy instruments for sustainable community development.

\subsection{Planning tools}

June 1997 marked the disappointing spectacle known as Earth Summit +5 , the required five-year follow-up to the Earth Summit held in Rio de Janiero in 1992. After all the eager promises made by Presidents and Prime Ministers in 1992, five years later it was only too clear that few of those promises would be kept. For example, despite commitments signed at the Rio Climate Convention in 1992 to stabilize greenhouse gas emissions at 1990 levels by 2000 , US emissions will probably have risen by $13 \%$ by 2000 , while Canadian emissions are forecast to rise $18 \%$ by 2010 .

The same kinds of promises are routinely broken closer to home, too. The road to sustainable development is paved with failed efforts to incorporate the environment into everyday municipal decision-making. Insincere politics may be partly to blame, but there is no doubt that even with the best intentions these kinds of commitments are wretchedly complex and difficult to keep. While progress in environmental management appears to be the order of the day, recent history gives cause for concern.

Toronto, for example, made headlines around the world in 1990 by becoming the first city to commit itself to reducing its 1988 level of carbon dioxide emissions $20 \%$ by 2005 . Included in its "call for action" was a goal of "significantly reducing the number of commuting autos" and a strategy to "promote significant reductions in the energy intensity of transportation in the city" by promoting public transit, bicycling and walking (City of Toronto, 1989). Yet ten years earlier Toronto City Council had passed an energy conservation by-law designed, among other things, to encourage development and redevelopment that would contribute to energy-efficient urban form, reduce the need for transportation, discourage automobile use and encourage public transit and bicycle transportation (Lang and Armour, 1982). That the same environmental legislation was passed twice in ten years is a strong indicator that the earlier measures were not implemented.

Another example of purported progress is the recent mushrooming of municipal and local government environmental departments, co-ordinators, task forces, staff committees, and citizen boards. At one level this certainly deserves applause. Yet a major survey of environmental management in nearly 3000 North American local governments in 1973 found that $20 \%$ had staff environment committees, $40 \%$ had designated environmental co-ordinators, and $24 \%$ had citizen environmental boards. Inadequate funding, uncertainty and delay in program administration, inadequate communication with senior levels of government, and inadequate technical assistance were all perceived in the mid-1970s as major impediments to adequate local responses to environmental problem solving (Magazine, 1977). More than a quarter-century later, this list still sounds all too familiar. 


\subsubsection{Managing community sustainability}

Moving toward sustainable communities is a long-term goal, so it is important that the incremental steps we take in the short-term are leading us in the right direction. This chapter briefly surveys some of the many tools available to citizens and their governments for managing community sustainability, and then discusses one of these tools, sustainability indicators, in more detail.

The tools described below (unless otherwise indicated, adapted from ICLEI, 1996 and from Levett, 1997) are organized into two categories: planning tools and assessment tools. Community planning and assessment tools can sometimes be conducted by citizen groups with little training, whereas technical planning and assessment tools more often require the involvement of trained staff or consultants. Technical planning and assessment tools may not lend themselves readily to public participation, but citizens can participate more effectively in decision-making if they know about many of the tools available to their communities.

\subsubsection{Community planning tools}

Several planning tools are useful for awareness building, problem diagnosis, and dialogue and participation in decision-making. These methods and tools can be used from the pre-planning through to the evaluation stages of the planning process. Relatively familiar or self-explanatory tools include Brainstorming, Community Meetings, Field Trips, Media Campaigns, Open House, Public Hearings, Public Meetings, Role Playing, Vision Building, and Workshops.

Popular education and search conferences may not be as well known. Popular education methods and tools include theatre, sculpturing, puppet shows, and storytelling. These media have grown out of the traditions of the communities in which development practitioners and educators have worked. Popular techniques engage the community in the identification and critical analysis of issues, information gathering related to these issues, and problem solving and decision-making methods related to development interventions. Popular education can enhance people's capacity to participate in decisions and actions affecting their lives.

Search conferences are two- to three-day strategic planning conferences designed to engage stakeholders in planning and managing the future. A search conference entails building consensus on a vision of the future as a basis for planning within and among all sectors. Future possibilities and trends rather than current problems or risks are made the focus of subsequent action planning. The elements of a search conference include a review of past and current trends, an analysis of external and internal forces, the creation of a future vision, and development of an action plan.

\subsubsection{Technical planning tools}

The following tools can be used to establish environmental carrying capacity limits and human impacts on them, and to guide policy.

Ecological Footprint Analysis (also discussed earlier) estimates the land area required by any human activity, both directly - the land occupied by buildings or infrastructure and indirectly - including the land needed to grow crops and assimilate pollutants. The ecological footprint may offer a meaningful single measure of all global ecological 
impacts of human activities, at household, municipal, national or global level. The degree to which the footprint of human activities exceeds the total productive area is a measure of unsustainability (Wackernagel and Rees, 1996).

Environmental Space estimates maximum sustainable rates of human use of key resources (energy, selected non-renewable resources, land, wood) and then divides these evenly among the world's population to give each individual's entitlement. The extent to which any country (or household) exceeds this is a measure of unsustainability. The calculations support calls for a tenfold "dematerialization" of western lifestyles.

Community-based State of the Environment (SOE) Reporting is inspired by national and international SOE reports. The idea of these efforts is to develop broad perceptions of ecosystems and our relationships with them, and to identify ecological approaches to planning and designing urban areas, on which residents and governments can ponder and act. As with all SOE reporting, the question of appropriate indicators presents a major challenge, especially at the local government level. Ideally, SOE indicators should be key measures that most represent the state of the environment and that collectively provide a comprehensive profile of environmental quality, natural resource assets, and agents of environmental change. Sustainability Reporting is State of Environment Reporting broadened to include quality of life as well as aspects of sustainability, and focused on information needed to guide decisions and action.

In Environmental Budgeting, local carrying capacities are used to set "budgets" for the maximum amount of environmental impact permissible in the municipal area. For example, the water extraction "budget" would be based on replenishment rates. The municipality works with all environmental "consumers" to keep impacts within budget. More consumption of water by households, for example, would have to be offset by less consumption by industry, or by more recovery/treatment of wastewater.

\subsubsection{Assessment tools}

Assessment tools are used for figuring out where we're at, and for monitoring and evaluating where we're going. Some familiar or self-explanatory assessment tools include Risk Assessment, Focus Groups, Periodic Monitoring Reports, Ranking, and Surveys. Some less familiar assessment tools are described below.

\subsubsection{Community assessment tools}

Community case studies are collective descriptions and analyses of the community and its problems, documented in a local language or medium (e.g. drawing, storytelling, role playing, audio-visual). They can be used to promote awareness and discussion among community members, and to gather baseline information for assessment.

Community environmental assessment can be used to involve stakeholders in gathering information and analysing the environmental and social impacts of proposed activities in an attempt to predict the positive and negative effects they may have. Designed for group observation and value judgment, the importance of any impact is determined by the community and given numerical value, such as environmental and social "scores." Although not useful in themselves, these scores can be used to facilitate priority setting and to identify indicators for monitoring and evaluation.

Community interviews are a form of survey, where all members of a community are 
invited to a meeting to answer specific pre-set questions. Discussion is restricted because the meeting size is large, so this tool is not useful for consensus building but rather to gather preliminary information on community perspectives or to solicit feedback on proposed strategies and actions.

Force field analysis is a facilitated and structured exercise in which participants identify specific hindering and facilitating forces affecting the functioning of any situation, assess the relative strength of each force, and plan alternative actions to overcome or promote these forces. It is useful for achieving a shared understanding of opportunities and constraints that can influence a desired goal, which helps participants determine which action strategies will be most effective and to set priorities.

Geographic information systems (GIS) are computer-based data systems for the storage, easy retrieval, manipulation, transformation, comparison, and graphic display of data. Intensive (and perhaps expensive) data gathering is often required, but once established, GIS can provide a user-friendly source of information that can be manipulated by non-experts as well as experts. In some communities, GIS systems have been used by community "watch-dogs" to monitor local environmental situations.

Community-based mapping involves residents in the pictorial construction of information about their community. During a mapping exercise, maps are constructed from local knowledge and observation, and provide an excellent starting point for discussion about community-based issue identification, analysis, and problem-solving.

Oral history is a participatory technique for information sharing during the analysis of local issues. Historical accounts can be compared with present information to generate an analysis of underlying trends and structural problems in a community, and can be used to inform residents about the history of changes and development in their community.

Service issues mapping is a facilitated group brainstorming and analysis technique that helps stakeholders "map" the diverse issues that must be considered in order to address a single priority issue. This exercise helps people see the systemic nature of local problems by highlighting complex sets of relationships among issues and by identifying different stakeholders who need to be involved in problem-solving.

SWOT Analysis (Strengths, Weaknesses, Opportunities, and Threats) is a strategic planning tool which will aid in the formulation of attainable long-range goals, action programs, and policies. Strengths and weaknesses refer to internal factors in the community, such as resources or declining budgets. Opportunities and threats refer to outside influences which could benefit or damage the community.

\subsubsection{Technical assessment tools}

The following tools can be used to assess effects of policies and/or actions, and to manage actions toward sustainability objectives.

Environmental Impact Assessment (EIA) and Social Impact Assessment (SIA) are comprehensive tools that integrate environmental and social considerations into project planning, development and implementation. In order to be effective, assessment has to be a decision making tool. The application of an effective assessment process ensures that potential environmental and social effects are identified and mitigative measures put in place to minimize or eliminate these impacts. Effective assessment requires that the environmental and social implications of a proposal be considered prior to taking or 
making irrevocable decisions and as early in the planning process as possible. The assessment of a proposal should include the concerns of the public with regard to both environmental and social evaluation (City of Ottawa, 1990).

Sustainability Appraisal (of activities, projects, programs, plans and/or policies) applies social and economic sustainability criteria as well as environmental ones, and considers the integration and reconciliation of different criteria.

An Environmental Audit (EA) is based on an assessment of the environmental impacts of a government's policies and practices. In some cases these will be known, or easily identifiable, while in others, it will be possible only to indicate the likely consequences. The policy review should encompass all activities of the government, and all departments and arms of its service. It should not be restricted to "official" or approved policy, because much local government practice has evolved through tradition, or results from informal decisions of staff (ACC, 1990).

Environmental Action Planning and Management is a variation on EA which involves setting environmental objectives, implementing environmental improvement actions, and monitoring and reporting on their effectiveness - in other words, applying familiar "management by objectives" to environmental effects.

Another variation on EA, Eco-Management and Audit System (EMAS) is a formal management systems standard for environmental "management by objectives." Originally designed for the manufacturing industry, it has been adopted for municipal use in the UK. A proposed update of EMAS, Sustainability Management and Audit System includes social and economic aspects of sustainability and strengthens involvement of stakeholders in setting criteria and assessing performance, according to social audit principles (see below).

Just as financial accounting measures financial performance, Social Auditing measures social performance by better understanding its relation to the goals and key stakeholders of an organization. Social auditing is increasingly popular with large private institutions such as Ben and Jerry's Ice Cream, The Body Shop International, and VanCity Savings Credit Union. It can also be applied to smaller businesses, community enterprises, co-operatives, non-governmental organizations and public bodies (Pearce et al., 1997).

Sustainability Indicators are an effective tool for communities and governments to evaluate their progress toward sustainability, and are discussed in more detail below.

\subsection{Tools in action}

In June 1992, the United Nations Conference on Environment and Development established Agenda 21, a sustainable development action plan for the 21 st century. That plan includes a proposal made by the International Council for Local Environmental Initiatives (ICLEI) to support local governments in the development of their own Local Agenda 21s. In response, ICLEI has established the Local Agenda 21 Initiative (ICLEI, 1993) to provide a common vehicle for local governments to strengthen local environmental planning and, thereby, to aid in the implementation of Agenda 21.

The purpose of ICLEI's Local Agenda 21 Initiative is to promote local campaigns to translate the UN Agenda 21 into local action plans. A Local Agenda 21 campaign can be any participatory, local effort to establish a comprehensive action strategy for sustainable development in that local jurisdiction or area. All local governments are urged to complete 
their campaigns and strategies and to report the results of their work to both the United Nations Commission on Sustainable Development and to ICLEI.

Local Agenda 21 campaigns support local governments in developing and introducing a sustainable development planning framework at the local level. ICLEI proposed a common planning framework based on four basic planning elements now in use, individually and in various combinations, by dozens of municipalities around the world. The four planning elements are:

- Community Consultation Processes, such as Round Tables, to achieve input and participation from every sector.

- Sustainable Development Auditing, to provide sound information about current conditions.

- Setting Sustainable Development Targets, both near- and long-term, for quality of life, environmental quality, resource consumption, and human development.

- Development and Use of Indicators, to inform the community about the impact of its programs and investments upon the sustainable development of the community.

From 1992 to 1996, approximately 1200 local governments in 33 countries established Local Agenda 21 campaigns (Brugmann, 1996).

The steps involved in developing sustainability indicators are to clarify goals (the aim of the evaluation and the type of desired outcome); determine who will lead the process; invite participation (the process of evaluation may be as valuable as the eventual application of the indicators themselves); decide how to choose indicators; collect data by which to measure the indicators; report on the indicators; and update and revise the indicators. (Details on these steps and related issues can be found in McLemore and Neumann, 1987; Forss et al., 1994; Schön and Rein, 1994; Parker, 1995; Waddell, 1995; Azar et al., 1996; Maclaren, 1996; Papineau, 1996; Brugmann, 1997; Kline, 1997; Schwandt, 1997).

The following initiatives represent a small sample of ongoing and emerging projects to design and use sustainability indicators. They were chosen to represent the spectrum of aims for which sustainability indicators can be used - from the Sustainable Seattle Project with a focus primarily on community education and empowerment to the Oregon Benchmarks project with a greater focus on providing feedback to government agencies. It is still early to judge the impact of these projects on community sustainability in the long term, but they seem to be helping these communities and regions move in a sustainable direction.

The Sustainable Seattle Project began in 1992 with a meeting of 150 citizens. During this gathering, ninety-nine indicators were proposed. From this initial list, forty key indicators were selected. The first twenty of these indicators were assessed in a 1993 report, and a 1995 report updates the first twenty indicators and reports on the remaining twenty. Indicators used ranged from total water consumption and per capita waste generation and recycling rates to volunteering in schools and household incomes. The Sustainable Seattle Project plans to update and improve their indicators on an annual basis.

In southwest Washington State, the Willapa Bay indicators project is significant as an attempt to evaluate the environmental, social and economic sustainability of a rural watershed. A joint effort by the Willapa Alliance and Ecotrust, the Willapa Indicators for a Sustainable Community (WISC) report is intended to promote discussion of 
sustainability issues in the local communities. The WISC indicators explicitly tie the health of the environment to the vitality of the local economy and community. Environmental indicators are divided into three categories: water resource quality, land use/vegetation patterns, and species populations. Economic indicators are included under the categories of productivity, opportunity, diversity, and equity. Finally, community measures fall under life-long learning, health, citizenship, and stewardship.

The WISC project, while primarily a project for community empowerment and education, is also linking their efforts to other community groups and organizations by publishing The Directory of Organizations and Services in Pacific County, Including Key Government Officials as a companion volume to their indicators report. The Willapa Alliance is also involved in several local projects to translate their evaluation exercise into tangible action. Among other projects, the Willapa Alliance has formed the Willapa Science Group. This group of local and regional scientists and educators is encouraging scientific research that is meaningful to local people. Such initiatives are vital to bridge the gap which exists in evaluation for community empowerment between the understandability of indicators and their scientific validity.

In Ontario, Hamilton-Wentworth's Sustainable Community Indicators Project arose out of the regional municipality's Vision 2020 initiative. This vision of a sustainable future was developed by a citizens' Task Force on Sustainable Development appointed by the Regional Council. While the vision process was initiated by the local government, it was able to draw on widespread community participation, with over 400 individuals and 50 community groups taking part (Maclaren, 1996). The Sustainable Community Indicators Project is an attempt to measure progress toward the goals outlined in the Vision 2020 document. As with Vision 2020, the municipality recognized and drew on the participation of the community throughout the indicators project. While the final set of indicators are intended to be of use to decision makers, the prime goal was to develop a set of indicators which were understandable and useful to local citizens. Consideration of the way in which indicators can be used by government agencies begins to move this evaluation process toward the approach used in Oregon and elsewhere which aims at providing feedback to the organizations responsible for strategic planning and implementation.

The Oregon Progress Board was established by the Oregon Legislature in 1989. The board, a multi-stakeholder organization, was originally charged with developing strategies and programs to support the state's strategic plan, "Oregon Shines." Out of this came the Oregon Benchmarks process. The Progress Board presented the reporting framework to the state legislature after extensive consultation and the benchmarks process was officially adopted in 1991 .

The framework for reporting consists of 269 indicators. Rather than simply present indicators to measure and report trends, however, the Oregon process defines targets, known as benchmarks. The benchmarks cover a diverse range of issues around sustainability, including categories such as children and families, education and work force, health and health care, clean natural environment, equal opportunity and social harmony, and economic prosperity. The board publishes a report card every two years to report on progress toward the stated targets.

While the Oregon Benchmarks program has drawn on public consultation and aims to inform the public, its main strength is its ability to promote action and accountability in the 
State Government. Benchmarks are now used as a tool to set program and budget priorities and to encourage interagency co-operation on broad issues. Each state agency has been directed to develop results-oriented performance measures that dovetail with the benchmarks. Through the Oregon Benchmarks program, rational and clear sustainability goals have formed the basis for strategic planning throughout government agencies. The legislature has even passed several bills directing agencies to work toward benchmarks. On a smaller scale, the Oregon Benchmarks are being applied by municipal governments and community organizations and several cities and counties are adopting strategies to complement the state program.

\subsubsection{Alternative national accounts}

This chapter has focused on managing community sustainability by citizens and governments at the local and regional scale. While this is an essential step in moving toward sustainable communities, there are wider circles of evaluation that are being developed; these include evaluation of sustainability at the national scale and evaluation of the social and environmental impacts of private corporations.

Many researchers have recognized the importance of developing indicators of progress toward sustainability at the national scale. Currently, much national policy is driven by trends in the Gross National Product (GNP) which only considers narrow economic measures of a country's well-being. Sustainability, including trends in natural and social capital, is not considered. Effective indicators of national sustainability would provide important information for citizens and governments trying to support initiatives at the local and regional level. 


\section{CHAPTER 8}

\section{Conclusion: the challenge ahead}

Sustainable community development will not come easily - it requires significant change in our structures, attitudes and values. Sustainable development implies a shift in the capacity of individuals, companies and nations to use resources which they have the right to use - and are encouraged to use - under present legal and economic arrangements. Although even the most conventional analyses recognize the need for changing these arrangements, few openly acknowledge that moving toward a sustainable society requires more than minor adjustments to existing practices.

Wachtel (1989) observes that the key to a sustainable future lies not in making us more competitive but rather in making us more perceptive, more able to realize what we have, what we need, and what are the long-term consequences of the short-term choices we are making. Many North Americans intuitively understand that the reason why economic growth no longer brings a sense of greater well-being, why the pleasures our new possessions bring swiftly melt away, is that at the level of affluence of the North American middle class "what really matters is not one's material possessions but one's psychological economy, one's richness of human relations and freedom from the conflicts and constrictions that prevent us from enjoying what we have." Indeed, we have attempted "to use economics to solve what are really psychological problems."

Like others writing in the growing sociological literature on the "communitarian approach" (e.g. Bellah et al., 1991; Lasch, 1991), Wachtel argues that our societal focus on productivity and economic efficiency as defining values leads to greater emphasis on competition, the pursuit of self-interest, and the stimulation of demand.

This in turn means still more decline in the security to be gained via shared ties and a stable, securely rooted place and way of life, still more need to compensate by organizing everything around what enables us to have 'more,' still more decline of traditional sources of security, and so forth. Thus, the more fully we have committed ourselves to increasing material abundance as our ultimate societal value, the more we have undermined older sources of security and made ourselves dependent on material goods for our sense of well-being to an unprecedented degree (Wachtel, 1989).

The challenge ahead is to explore the implications of a sustainable future and to find a new set of guiding images and metaphors suited for it. Sustainable communities are the next steps in suggesting an alternative vision of the future that is not just a bitter necessity (for example, the need to reduce materials and energy consumption) but holds out promise of a genuinely better life. Sustainable communities do not mean settling for less, but rather thinking of new opportunities along a different, and likely more satisfying, dimension.

Within this larger context, the perspective detailed in this article can be viewed as illustrative of values that are prerequisite for a sustainable society. Sustainable community development initiatives themselves serve not only as points of intervention, but also as processes for social learning by which communities can mobilize positive change toward a sustainable society. Developing a sustainable society requires both shifting away from 
values which encourage unsustainable behaviours and also shifting toward values which promote sustainable practices. As portrayed by these initiatives, active social learning programs - attempts through social experimentation to change social behaviour - can be effective not only in preventing a host of environmental and related social disasters, but also in creating healthy, sustainable communities which will be more pleasant and satisfying for their residents than the communities we live in today.

With their relatively wealthy and well-educated populations, North American communities have a moral obligation to demonstrate leadership (and consequently benefit from) developing the knowledge, technologies, and processes the world requires for sustainability in the coming decades. Citizens and their governments have the ability to frame issues, assume leadership, champion initiatives, and demonstrate sustainable alternatives in their everyday practice. With creative leadership we may yet be able to leave our children a legacy of which we can be proud.

Sustainable communities require unprecedented and simultaneous emphasis on the efficient use of urban space, on minimizing the consumption of essential natural capital, on multiplying social capital, and on mobilizing citizens and their governments toward these ends. This synergistic approach will enable our communities to be cleaner, healthier, and less expensive; to have greater accessibility and cohesion; and to be more self-reliant in energy, food and economic security than they are now. Sustainable communities will not, therefore, merely "sustain" the quality of our lives - they will dramatically improve it.

\section{Acknowledgements}

Many people have helped with the development of these ideas over the years. In particular, I am obliged to Joan Fletcher for background research on social capital, to Ryan Hill for research assistance on policy instruments, to Dorli Duffy for research on shared decision-making, and to Zane Parker for research on sustainability indicators. I also gratefully acknowledge financial support for this project from the President's Research Fund at Simon Fraser University, and from the Science Council of British Columbia for research on policy instruments.

\section{References}

Aberley, D., 1993. Boundaries of Home: Mapping for Local Empowerment, New Society Publishers, Gabriola Island, British Columbia.

Aberley, D. (Ed.), 1994. Futures By Design: The Practice of Ecological Planning New Society Publishers, Gabriola Island, British Columbia.

Agyeman, J., Evans, B. (Eds.), 1996. Statement of Purpose, Local Environment, 1(1).

Alcamo, J.M., 1990. Compact City Design as a Strategy to Cut Dangerous Air Pollution, presented to the First International Ecocity Conference, Berkeley, CA. Urban Ecology, 29 March-1 April 1990.

Alexander, E.R., 1988. After rationality. Society 26 (1), 15-19.

Alexander, N., 1991. Fifteen ways to make growth management work. In: Degrove, J.M. (Ed.). Balanced Growth: A Planning Guide for Local Government, International City Management Association, Washington, DC. Arnstein, S.R., 1969. A ladder of citizen participation. Journal of American Institute of Planners, 216-224. 
Azar, C., Holmberg, J., Lindgren, K., 1996. Socio-ecological indicators for sustainability. Ecological Economics $18,89-112$.

Bellah, R.N., et al., 1991. The Good Society, Knopf, New York.

Berg, P., et al., 1989. A Green City Program for San Francisco Bay Area Cities and Towns, Planet Drum Books, San Francisco, CA.

Boggs, D., 1990. Adult Civic Education, Charles C. Thomas, Springfield, IL.

Bookchin, M., 1987. The Rise of Urbanization and the Decline of Citizenship, Sierra Club, San Francisco, CA.

Boothroyd, P., 1991. Community Economic Development: An Introduction for Planners, UBC Centre for Human Settlements, Vancouver.

Brandt, B., 1995. Whole Life Economics: Revaluing Daily Life, New Society Publishers, Gabriola Island, BC.

Brohman, J., 1996. Popular Development: Rethinking the Theory and Practice of Development, Blackwell, Oxford.

Brown, L.R., et al., 1998. State of the World 1988: A Worldwatch Institute Report on Progress Toward a Sustainable Society, W.W. Norton, New York/London.

Browne, P.L., 1996. Love in a Cold World: The Voluntary Sector in an Age of Cuts, Canadian Centre for Policy Alternatives, Ottawa.

Brugmann, J., Hersh, R., 1991. Cities as Ecosystems: Opportunities for Local Government. ICLEI, Toronto (draft).

Brugmann, J., 1996. Cities Take Action: Local Environmental Initiatives, in World Resources Institute, United Nations Environment Program, United Nations Development Program, The World Bank, World Resources 1996-97: The Urban Environment, Oxford University Press, New York.

Brugmann, J., 1997. Is There a Method in Our Measurement? The use of indicators in local sustainable development planning. Local Environment 2 (1), 59-72.

Burchell, R.W., 1988. The incongruity of theory and practice. Society 26 (1), 4.

California Office of Appropriate Technology (CalOAT), 1981. Working Together: Community Self-Reliance in California. California Office of Appropriate Technology, Sacramento.

Callicott, J.B., 1982. Traditional American Indian and Western European attitudes toward nature: an overview. Environmental Ethics 4, 293-318.

Calthorpe, P., 1989. Introduction: a reverse definition. In: Kelbaugh, D. (Ed.). The Pedestrian Pocket Book: A New Suburban Design Strategy, Princeton Architectural Press, New York.

Capra, F., Spretnak, C., 1984. Green Politics: The Global Promise, E.P. Dutton, New York.

City of Vancouver, 1990. Clouds of Change: Final Report of the City of Vancouver Task Force on Atmospheric Change. City of Vancouver, Vancouver, June 1990.

Coleman, J.S., 1988. Social capital in the creation of human capital. American Journal of Sociology (supplement) 94, S95-S120.

Coleman, J.S., 1990. Foundations of Social Theory, Harvard University Press, Cambridge, MA.

Conference Statement, 1988. The Changing Atmosphere: Implications for Global Security. Toronto, Ontario, 27-30 June 1988.

Coover, V., et al., 1977. Resource Manual for a Living Revolution, New Society Publishers, Philadelphia.

Cormick, G., 1989. Strategic issues in structuring multi-party public policy negoticontribution. Negotiation Journal 5 (2), 125-132.

Crowfoot, J.E., Wondolleck, J.M., 1990. Environmental Disputes: Community Involvement in Conflict Resolution, Island Press, Washington, DC/ Covelo, CA.

Daly, H.E., 1989. Sustainable Development: From Concept and Theory Towards Operational Principles. In: Population and Development Review, Hoover Institution Conference.

Daly, H.E., Cobb Jr, J.B., 1989. For the Common Good: Redirecting the Economy Toward Community, the Environment, and a Sustainable Future, Beacon Press, Boston.

Darrow, K., et al., 1981. Appropriate Technology Sourcebook, Volunteers in Asia, Stanford, CA.

Dodge, J., 1981. Living by Life: Some Bioregional Theory and Practice. CoEvolution Quarterly 32, 6-12.

Duffy, D., Roseland, M., Gunton, T.I., 1996. A preliminary assessment of shared decision-making in land use and natural resource planning. Environments: A Journal of Interdisciplinary Studies 23 (2), 1-16.

Ekins, P. (Ed.), 1986. The Living Economy: A New Economics in the Making Routledge, London.

Feitelson, S.K., 1998. Muddling toward sustainability: the transformation of environmental planning in Israel. Progress in Planning 49 (1), 1-54. 
Flavin, C., 1990. Slowing global warming. In: Brown, L.R. (Ed.). State of the World 1990: A Worldwatch Institute Report on Progress Toward a Sustainable Society, W.W. Norton, New York/London, pp. 17-38.

Flora, C.B., Flora, J.L., 1993. Entrepreneurial social infrastructure: a necessary ingredient. Annals of the American Academy of Political and Social Science 529, 48-58.

Forss, K., Cracknell, B., Samset, K., 1994. Can evaluation help an organization to learn? Evaluation Review 18 (5), 574-591.

Foster, T.W., 1987. The Taoists and the amish: kindred expressions of eco-anarchism. The Ecologist 17 (1), 9-14.

Friedmann, J., 1987. Planning in the Public Domain, Princeton University Press, Princeton.

Gibson, R., 1991. Should environmentalists pursue 'sustainable development'? Probe Post 13 (4), 22-25.

Gibson, R.B., Alexander, D.H.M., Tomalty, R., 1997. Putting cities in their place: ecosystem-based planning for canadian urban regions. In: Roseland, M. (Ed.). Eco-City Dimensions: Healthy Communities, Healthy Planet, New Society Publishers, Gabriola Island, BC.

Gilbert, R., Stevenson, D., Giradet, H., Stren, R., 1996. Making Cities Work: The Role of Local Authorities in the Urban Environment, Earthscan, London.

Gran, G., 1987. An Annotated Guide to Global Development: Capacity Building for Effective Social Change. University of Pittsburgh Economic and Social Development Program, Pittsburgh.

GreenClips, 1997.76, 16 July 1997, GreenClips@aol.com

Hamilton, E., 1992. Adult Education for Community Development, Greenwood Press, New York.

Harvey, D., 1996. Cities or urbanization. City Magazine (London, UK) 1, 2.

Haughton, G., Hunter, C., 1994. Sustainable Cities, Regional Policy and Development Series, 7, Jessica Kingsley, London.

Henderson, H., 1991. Paradigms in Progress: Life Beyond Economics, Knowledge Systems, Indianapolis.

Henderson, H., 1996. Building a Win-Win World: Life Beyond Global Economic Warfare, Berrett-Koehler Publishers, San Francisco, CA.

Hiss, T., 1990. The Experience of Place, Alfred A. Knopf, New York.

Holmberg, J., Bass, S., Timberlake, L., 1991. Defending the Future: A Guide to Sustainable Development. International Institute for Environment and Development/Earthscan, London.

ICPQL, 1996 (Independent Commission on Population and Quality of Life). Caring for the Future: A Radical Agenda for Positive Change. Oxford University Press, Oxford.

ICLEI, 1993 (International Council for Local Environmental Initiatives). The Local Agenda 21 Initiative: ICLEI Guidelines for Local and National Local Agenda 21 Campaigns. ICLEI, Toronto.

ICLEI, 1995 (International Council for Local Environmental Initiatives). The Role of Local Authorities in Sustainable Development: 14 Case Studies on the Local Agenda 21 Process. UN Centre for Human Settlements, Nairobi.

ICLEI, 1996 (International Council for Local Environmental Initiatives). ICLEI, International Development Research Centre (IDRC), and United Nations Environment Programme (UNEP), The Local Agenda 21 Planning Guide. ICLEI, Toronto and IDRC, Ottawa, 1996.

IUCN, 1980 (International Union for the Conservation of Nature and Natural Resources). World Conservation Strategy. IUCN, Gland.

Jacobs, J., 1961. The Death and Life of Great American Cities, Random House, New York.

Jacobs, M., 1993. The Green Economy: Environment, Sustainable Development, and the Politics of the Future, University of British Columbia Press, Vancouver.

Jacobs, M., 1997. The new politics of the environment. In: Jacobs, M. (Ed.). Greening the Millennium? Blackwell Publishers, Oxford.

Jansson, A.M., Hammer, M., Folke, C., Costanza, R. (Eds.), 1994. Investing in Natural Capital: The Ecological Economics Approach to Sustainability Island Press, Washington, DC.

Karasek, R., Theorell, T., 1990. Healthy Work: Stress, Productivity and the Reconstruction of Working Life, Basic Books, New York.

Kline, E., 1997. Sustainable community indicators. In: Roseland, M. (Ed.). Eco-City Dimensions: Healthy Communities, Healthy Planet, New Society Publishers, Gabriola Island, BC.

Korten, D., 1995. When Corporations Rule the World, Berrett-Koehler Publishers, San Francisco, CA.

Langton, J., 1997. City's Plan to Kill Stray Cats Raises a Howl. Vancouver Sun, August 11, p. A8.

Lasch, C., 1991. The True and Only Heaven: Progress and Its Critics, W.W. Norton, New York. 
Lemann, N., 1996. Kicking in groups. Atlantic Monthly 277 (4), 22-26.

Lerner, S., 1994. The future of work in North America: good jobs, bad jobs, beyond jobs. Futures 26(2).

Levett, R., 1997. Tools, techniques and processes for municipal environmental management. Local Environment 2 (2), 189-202.

Lowe, M.D., 1992. Shaping Cities: The Environmental and Human Dimensions. Worldwatch Institute, Paper 105, Washington, DC.

Maclaren, V.W., 1996. Developing Indicators of Urban Sustainability: A Focus on the Canadian Experience. Intergovernmental Committee on Urban and Regional Research (ICURR) Press, Toronto.

Mandelbaum, S.J., 1988. Open moral communities. Society 26 (1), 27.

Mazza and Ryden, (ed.), (1997). Urban Sustainability: Discourses, Networks and Policy Tools. Progress in Planning 47(1).

McKibben, B., 1996. The enigma of Kerala: one state in India is proving development experts wrong. Utne Reader 74, 102-112.

McLemore, J.R., Neumann, J.E., 1987. The inherently political nature of program evaluators and evaluation research. Evaluation and Program Planning 10, 83-93.

McNeeley, J.A., Pitt, D. (Eds.), 1985. Culture and Conservation: the Human Dimension in Environmental Planning, Croom Helm, New York.

Meadows, D.H., et al., 1972. The Limits to Growth, Signet, New York.

Meadows, D., et al., 1992. Beyond the Limits, Chelsea Green, Post Mills, VT.

M'Gonigle, M., 1991. Recasting the national debate. The Canadian Forum LXX (802), 11-15.

Minnery, J.R., 1985. Conflict Management in Urban Planning, Gower, Brookfield, VT.

Minnesota SEDEPTF, 1995 (Sustainable Economic Development and Environmental Protection Task Force). Common Ground: Achieving Sustainable Communities in Minnesota. Minnesota Planning, St. Paul.

Mitlin, D., Satterthwaite, D., 1991. Sustainable Development and Cities, prepared for How Common Is Our Future? A Global NGO Forum. Habitat International Coalition, Mexico City, 4-7 March 1991.

Mollison, B., 1978. Permaculture One. International Tree Crops Institute, Winters, CA.

Mollison, B., 1979. Permaculture Two. International Tree Crops Institute, Winters, CA.

Morris, D., 1982. Self-Reliant Cities: Energy and the Transformation of Urban America, Sierra Club Books, San Francisco, CA.

Morris, D., 1990. The ecological city as a self-reliant city. In: Gordon, D. (Ed.). Green Cities: Ecologically Sound Approaches to Urban Space, Black Rose Books, Montreal, pp. 21-35.

Morris, D., 1990. An Environmental Policy for the 1990s: Fashioning the Molecular Basis for a Green Economy, Institute for Local Self-Reliance, Washington, DC.

NRTEE, 1993 (National Round Table on the Environment and the Economy). Building Consensus for a Sustainable Future: Guiding Principles. NRTEE, Ottawa.

NTFEE, 1987 (National Task Force on Environment and Economy). Report of the National Task Force on Environment and Economy. Canadian Council of Resource and Environment Ministers, Ottawa.

Newman, P., 1990. Social organization for ecological sustainability: toward a more sustainable settlement pattern. In: Cook, P. (Ed.), Social Structures for Sustainability. Fundamental Questions Paper No. 11, Centre for Resource and Environmental Studies, Australian National University, Canberra.

O’Hara, B., 1993. Working Harder Isn’t Working, New Star Books, Vancouver.

O’Hara, B., 1994. Put Work In Its Place, New Star Books, Vancouver.

Olkowski, H., et al., 1979. The Integral Urban House: Self-Reliant Living in the City, Sierra Club Books, San Francisco,CA.

ORTEE, 1995 (Ontario Round Table on the Environment and the Economy). Sustainable Communities Resource Package, ORTEE, Toronto.

Osborne, D., Gaebler, T., 1993. Reinventing Government, Plume, New York.

Ostrom, E., 1993. Social Capital and Development Projects. Unpublished paper prepared for workshop "Social Capital and Economic Deveopment," American Academy of Arts and Sciences, Cambridge, MA, 30-31 July 1993.

Owens, S.E., 1990. Land use planning for energy efficiency. In: Cullingworth, J.B. (Ed.). Energy, Land, and Public Policy, Transaction Publishers, New Brunswick, NJ, pp. 53-98.

Paehlke, R., Torgerson, D. (Eds.), 1990. Managing Leviathan: Environmental Politics and the Administrative State, Broad View Press, Peterborough. 
Papineau, D., 1996. Participatory evaluation in a community organization: fostering stakeholder empowerment and utilization. Evaluation and Program Planning 19 (1), 79-93.

Parker, P., 1995. From sustainable development objectives to indicators of progress: options for New Zealand communities. New Zealand Geographer 51 (2), 50-57.

Pearce, D.W., Barbier, E., Markandya, A., 1989. Blueprint for a Green Economy, Earthscan Publications, London.

Pearce, D.W., Barbier, E., Markandya, A., 1990. Sustainable Development: Economics and Environment in the Third World, Gower, Brookfield, VT.

Pearce, J., Raynard, P., Zadek, A., 1997. Social Auditing for Small Organizations: A Workbook for Trainers and Practitioners, New Economics Foundation, London.

Pietila, H., 1990. Environment and sustainable development. IFDA dossier 77, 61-70, May/June 1990.

President's Council on Sustainable Development, 1996. Sustainable America: A New Consensus for Prosperity, Opportunity, and a Healthy Environment for the Future. US Government Printing, Washington, DC.

Putnam, R., Leonardi, R., Nanetti, R., 1993. Making Democracy Work: Civic Traditions in Modern Italy, Princeton University Press, Princeton, NJ.

Putnam, R.D., 1995. Bowling alone: America's declining social capital. Journal of Democracy 6 (1), 65-78.

Rabinovitch, J., 1996. Integrated Transportation and Land Use Planning Channel Curitiba's Growth, in World Resources Institute, United Nations Environment Program, United Nations Development Program, The World Bank, World Resources 1996-97: The Urban Environment, Oxford University Press, New York.

RAIN, 1981. Knowing Home: Studies for a Possible Portland. Rain Umbrella Inc., Portland.

Rees, W.E., 1990. Sustainable Development and the Biosphere: Concepts and Principles. Teilhard Studies No. 22. Anima Books for the American Teilhard Association, Chambersburg, PA.

Rees, W.E., 1990. The ecology of sustainable development. The Ecologist 20 (1), 18-23.

Rees, W.E., 1991. Economics, ecology, and the limits of conventional analysis. Journal of the Air and Waste Management Asssociation 41 (10), 1323-1327.

Rees, W.E., 1992a. Understanding Sustainable Development: Natural Capital and the New World Order. School of Community and Regional Planning, Vancouver, UBC.

Rees, W.E., 1992b. Ecological Footprints and Appropriated Carrying Capacity: What Urban Economics Leaves Out. Presented to Globe'92, Vancouver, British Columbia, 18 March 1992.

Replogle, M., 1990. Sustainable Transportation Strategies for World Development. Presented to the World Congress of Local Governments for a Sustainable Future, United Nations, New York, 7 September 1990.

Rifkin, J., 1995. The End of Work: The Decline of the Global Labour Force and the Dawn of the Post-Market Era, G.P. Putnam, New York.

Rose, R., 1996. Social Capital: Definition, Measure, Implications. Unpublished remarks at a World Bank Workshop on Social Capital, 16-17 April 1996.

Roseland, M., 1997. Eco-city dimensions: healthy communities, healthy planet. In: Roseland, M. (Ed.). New Society Publishers, Gabriola Island, BC.

Roseland, M., 1998. Toward Sustainable Communities: Resources for Citizens and Their Governments, New Society Publishers, Gabriola Island, BC.

Roseland, M., Jacobs, M., 1995. Sustainable Development, Economic Instruments, and the Sustainable Management of Aquatic Resources and Ecosystems: A New Framework for Water Management in the Fraser River Basin, School of Resource and Environmental Management, Simon Fraser University, Burnaby, BC.

Ryle, M., 1988. Ecology and Socialism, Radius, London.

Sale, K., 1985. Dwellers in the Land: The Bioregional Vision, Sierra Club, San Francisco, CA.

Schon, D., 1983. The Reflective Practitioner: How Professionals Think in Action, Basic Books, New York.

Schön, D.A., Rein, M., 1994. Frame Reflection: Toward the Resolution of Intractable Policy Controversies, Basic Books, New York.

Schor, J.B., 1991. Global equity and environmental crisis: an argument for reducing working hours in the north. World Development 19 (1), 73-84.

Schor, J.B., 1992. The Overworked American, Basic Books, New York.

Schumacher, E.F., 1973. Small is Beautiful: A Study of Economics as if People Mattered, Harper \& Row, New York.

Schwandt, T.A., 1997. Evaluation as practical hermeneutics. Program Evaluation 3 (1), 69-83. 
Selman, P. and Parker, J., 1997. Citizenship, Civicness and Social Capital in Local Agenda 21. Local Environment 2(2).

Senge, P., 1990. The Fifth Discipline, Double Day Currency, New York.

Shea, C.P., 1994. Employment and Sustainable Development: Opportunities for Canada. International Institute for Sustainable Development, Winnipeg.

Sieghart, P., 1986. The Lawful Rights of Mankind, Oxford University Press, Oxford/New York.

SFU CEDC, 1996 (Simon Fraser University, Community Economic Development Centre). Our Working Definition of CED, SFU CEDC home page, http://www.sfu.ca/cede/.

Smith, E.J., 1989. A Perspective from a Nuu-chah-nulth on Planning Sustainable Communities. In: Rees, W.E. (Ed.). Planning for Sustainable Development: A Resource Book, UBC Centre for Human Settlements, Vancouver, pp. 127-129.

Surpin, R., Bettridge, T., 1986. Refocusing Community Economic Development. Economic Development \& Law Center Report, Spring 1986, pp. 36-42.

Swanson, L., 1992. Rural social infrastructure. In: Reid, J.N. (Ed.). Foundations of Rural Development Policy, Westview Press, Boulder, CO.

Swift, R., 1987. What if the greens achieved power? (reprinted version). Utne Reader 23, 32-33 (also in New Internationalist, May 1987).

Tokar, B., 1987. The Green Alternative, R. \& E. Miles, San Pedro.

Toronto Declaration on World Cities and Their Environment, 1991. World Cities and Their Environment Congress of Municipal Leaders. Toronto, 28 August 1991.

Trainer, T., 1990. A Rejection of the Brundtland Report. ifda dossier 77, 71-84, May/June 1990.

United Nations Conference on Environment and Development, 1992. Outcomes of the Conference. UNCED Agenda 21, Rio de Janiero, Brazil, June 1992.

UNEP, 1990 (United Nations Environment Program). Call to a World Congress of Local Governments for a Sustainable Future. United Nations, New York, 5-8 September 1990.

University of British Columbia (UBC) Task Force on Healthy and Sustainable Communities, 1994. Tools for sustainability: iteration and implementation. In: Chu, C., Simpson R., (Eds.), The Ecological Public Health: From Vision to Practice. University of Toronto Centre for Health Promotion and Institute for Applied Environmental Research at Griffith University, Australia.

Urban Ecology, 1996. Blueprint for a Sustainable Bay Area. Urban Ecology, Oakland.

Van der Ryn, S., Calthorpe, P., 1986. Sustainable Communities: A New Design Synthesis for Cities, Suburbs, and Towns, Sierra Club Books, San Francisco, CA.

Wackernagel, M., Rees, W., 1996. Our Ecological Footprint: Reducing Human Impact on the Earth, New Society Publishers, Gabriola Island, BC.

Wachtel, P., 1989. The Poverty of Affluence: A Psychological Portrait of the American Way of Life, New Society Publishers, Gabriola Island, BC.

Waddell, S., 1995. Lessons from the healthy cities movement for social indicator development. Social Indicators Research 34, 213-235.

White, R., Whitney, J., 1990. Human Settlements and Sustainable Development: An Overview. University of Toronto Centre for Urban And Community Studies; draft prepared for the Colloquium on Human Settlements and Sustainable Development, 21-23 June 1990.

WCED (World Commission on Environment and Development), 1987. Our Common Future, Oxford University Press, New York.

WHO, 1986 (World Health Organization). Health and welfare Canada, and the Canadian public health association. Ottawa Charter for Health Promotion. Canadian Journal of Public Health 77, 425-427.

Yesney, M., 1990. The Sustainable city: a revolution in urban evolution. Western City LXVI (3), 4-44. 